\title{
\#USGS
}

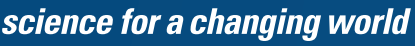

DOE/ID-22229

Prepared in cooperation with the U.S. Department of Energy

Completion Summary for Boreholes USGS 140 and USGS 141 near the Advanced Test Reactor Complex, Idaho National Laboratory, Idaho

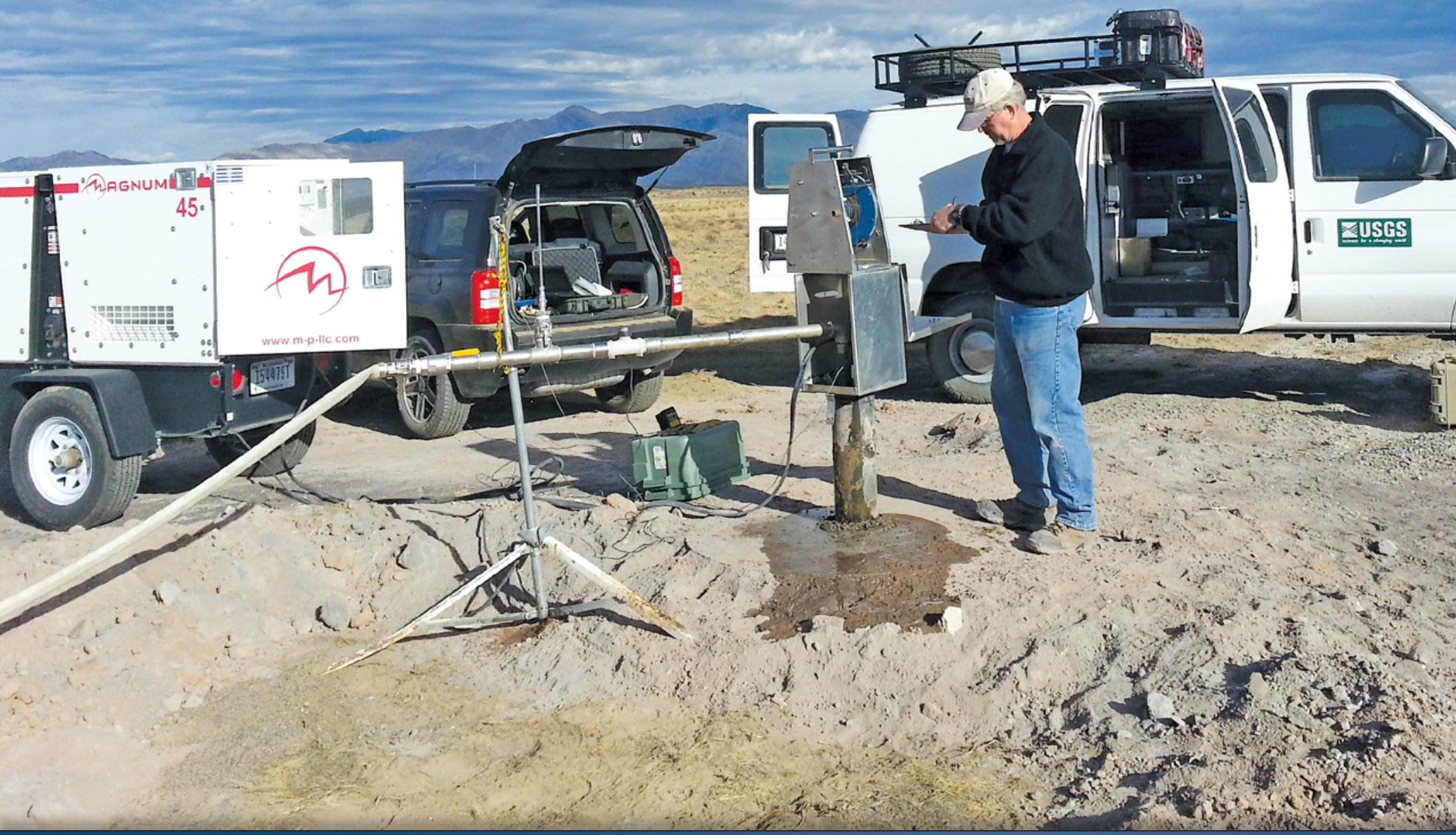

Scientific Investigations Report 2014-5098

U.S. Department of the Interior

U.S. Geological Survey 
Cover: Photograph of U.S. Geological Survey Hydrologic Technician (Neil Maimer) recording aquifer test drawdown data for newly completed well USGS 141. Photograph taken by Brian Twining, U.S. Geological Survey, September 24, 2013. 


\section{Completion Summary for Boreholes USGS 140 and USGS 141 near the Advanced Test Reactor Complex, Idaho National Laboratory, Idaho}

By Brian V. Twining, Roy C. Bartholomay, and Mary K.V. Hodges

DOE/ID-22229

Prepared in cooperation with the U.S. Department of Energy

Scientific Investigations Report 2014-5098 


\title{
U.S. Department of the Interior SALLY JEWELL, Secretary
}

\section{U.S. Geological Survey \\ Suzette M. Kimball, Acting Director}

\author{
U.S. Geological Survey, Reston, Virginia: 2014
}

For more information on the USGS - the Federal source for science about the Earth, its natural and living resources, natural hazards, and the environment, visit http://www.usgs.gov or call 1-888-ASK-USGS

For an overview of USGS information products, including maps, imagery, and publications, visit http://www.usgs.gov/pubprod

To order this and other USGS information products, visit http://store.usgs.gov

Any use of trade, firm, or product names is for descriptive purposes only and does not imply endorsement by the U.S. Government.

Although this information product, for the most part, is in the public domain, it also may contain copyrighted materials as noted in the text. Permission to reproduce copyrighted items must be secured from the copyright owner.

Suggested citation:

Twining, B.V., Bartholomay, R.C., and Hodges, M.K.V., 2014, Completion summary for boreholes USGS 140 and USGS 141 near the Advanced Test Reactor Complex, Idaho National Laboratory, Idaho: U.S. Geological Survey Scientific Investigations Report 2014-5098 (DOE/ID-22229), 40 p., plus appendixes, http://dx.doi.org/10.3133/ sir20145098.

ISSN 2328-0328 (online) 


\section{Contents}

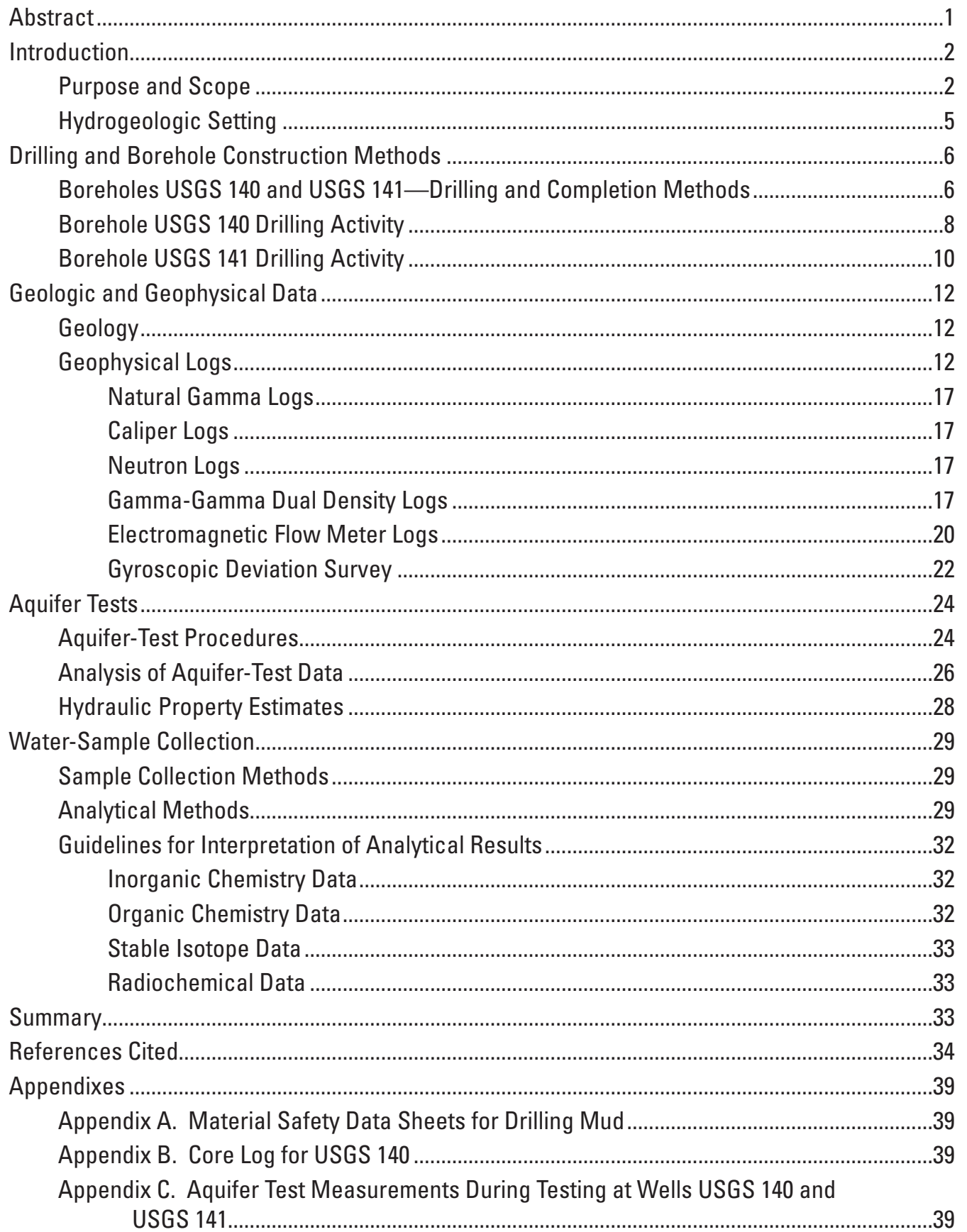




\section{Figures}

1. Map showing location of selected facilities and boreholes USGS 140 and USGS 141, Idaho National Laboratory, Idaho.

2. Map showing location of boreholes USGS 140 and USGS 141 and selected monitor wells, Advanced Test Reactor Complex and vicinity, Idaho National Laboratory, Idaho...

3. Diagram and graphs showing idealized typical olivine tholeiite pahoehoe basalt flow.

4. Diagram and photographs showing $\mathrm{HO}$-size coring system similar to one used for coring borehole USGS 140, Idaho National Laboratory, Idaho ...

5. Diagram showing final constructed borehole USGS 140, Advanced Test Reactor Complex, Idaho National Laboratory, Idaho..

6. Diagram showing final constructed borehole USGS 141, Advanced Test Reactor Complex, Idaho National Laboratory, Idaho...

7. Geophysical and lithologic logs run from total depth to land surface and lithologic logs described from cores, video logs, and geophysical logs for borehole USGS 140, Advanced Test Reactor Complex, Idaho National Laboratory, Idaho...

8. Geophysical and lithologic logs run from total depth to land surface for borehole USGS 141, Advanced Test Reactor Complex, Idaho National Laboratory, Idaho

9. Diagram showing borehole conditions during four stages of geophysical logging at boreholes USGS 140 and USGS 141, Advanced Test Reactor Complex, Idaho National Laboratory, Idaho.

10. Expanded geophysical and lithologic logs with focus on depths $480-545$ feet below land surface for borehole USGS 140, Advanced Test Reactor Complex, Idaho National Laboratory, Idaho.

11. Expanded geophysical and lithologic logs with focus on depths $480-545$ feet below land surface for borehole USGS 141, Advanced Test Reactor Complex, Idaho National Laboratory, Idaho.

12. Geophysical gamma-gamma dual density logs used to examine annular grout seal 0-480 feet below land surface for boreholes USGS 140 and USGS 141, Advanced Test Reactor Complex, Idaho National Laboratory, Idaho

13. Diagrams showing gyroscopic deviation data collected for boreholes USGS 140 and USGS 141, Advanced Test Reactor Complex, Idaho National Laboratory, Idaho.....23

14. Diagram showing idealized placement of sensors during aquifer testing at wells USGS 140 and USGS 141, Advanced Test Reactor Complex, Idaho National Laboratory, Idaho..

15. Graphs showing changes in barometric head and air temperature through time at well USGS 140, and well USGS 141, Advanced Test Reactor Complex, Idaho National Laboratory, Idaho.

16. Graph showing relation between transmissivity and specific capacity derived from aquifer testing for wells completed within the eastern Snake River Plain aquifer, Idaho

17. Graphs showing analyses of drawdown time series for aquifer tests at well USGS 140 and well USGS 141, Advanced Test Reactor Complex, Idaho National Laboratory, Idaho 


\section{Tables}

1. Location and construction information for boreholes USGS 140 and USGS 141, Advanced Test Reactor Complex, Idaho National Laboratory, Idaho .............................10

2. Summary of geophysical and video log data collected at boreholes USGS 140 and USGS 141, Advanced Test Reactor Complex, Idaho National Laboratory, Idaho

3. Summary of gyroscopic deviation data from processed survey for boreholes USGS 140 and USGS 141, Advanced Test Reactor Complex, Idaho National Laboratory, Idaho

4. Comparison of transmissivity values estimated from aquifer tests at wells near wells USGS 140 and USGS 141, near the Advanced Test Reactor Complex, Idaho National Laboratory, Idaho.

5. Concentrations of selected chemical and radiochemical constituents in water from wells USGS 140 and USGS 141, near the Advanced Test Reactor Complex, Idaho National Laboratory, Idaho. 


\section{Conversion Factors, Datums, and Abbreviations and Acronyms}

\section{Conversion Factors}

\begin{tabular}{|c|c|c|}
\hline Multiply & By & To obtain \\
\hline \multicolumn{3}{|c|}{ Length } \\
\hline inch (in.) & 2.54 & centimeter $(\mathrm{cm})$ \\
\hline foot $(\mathrm{ft})$ & 0.3048 & $\operatorname{meter}(\mathrm{m})$ \\
\hline mile (mi) & 1.609 & kilometer (km) \\
\hline \multicolumn{3}{|c|}{ Volume } \\
\hline gallon (gal) & 3.785 & liter $(\mathrm{L})$ \\
\hline cubic foot $\left(\mathrm{ft}^{3}\right)$ & 28.32 & cubic decimeter $\left(\mathrm{dm}^{3}\right)$ \\
\hline cubic foot $\left(\mathrm{ft}^{3}\right)$ & 0.02832 & cubic meter $\left(\mathrm{m}^{3}\right)$ \\
\hline liter $(\mathrm{L})$ & 33.82 & ounce, fluid (fl. oz) \\
\hline \multicolumn{3}{|c|}{ Flow rate } \\
\hline foot per minute $(\mathrm{ft} / \mathrm{min})$ & 0.3048 & meter per minute $(\mathrm{m} / \mathrm{min})$ \\
\hline foot per day $(\mathrm{ft} / \mathrm{d})$ & 0.3048 & meter per day $(\mathrm{m} / \mathrm{d})$ \\
\hline gallon per minute (gal/min) & 0.06309 & liter per second $(\mathrm{L} / \mathrm{s})$ \\
\hline \multicolumn{3}{|c|}{ Pressure } \\
\hline atmosphere, standard (atm) & 101.3 & kilopascal (kPa) \\
\hline pound per square inch $\left(\mathrm{lb} / \mathrm{in}^{2}\right)$ & 6.895 & kilopascal (kPa) \\
\hline \multicolumn{3}{|c|}{ Radioactivity } \\
\hline picocurie per liter $(\mathrm{pCi} / \mathrm{L})$ & 0.037 & becquerel per liter $(\mathrm{Bq} / \mathrm{L})$ \\
\hline \multicolumn{3}{|c|}{ Specific capacity } \\
\hline $\begin{array}{l}\text { gallon per minute per foot } \\
\qquad[(\mathrm{gal} / \mathrm{min}) / \mathrm{ft})]\end{array}$ & 0.2070 & liter per second per meter $[(\mathrm{L} / \mathrm{s}) / \mathrm{m}]$ \\
\hline \multicolumn{3}{|c|}{ Hydraulic conductivity } \\
\hline foot per day (ft/d) & 0.3048 & meter per day $(\mathrm{m} / \mathrm{d})$ \\
\hline \multicolumn{3}{|c|}{ Hydraulic gradient } \\
\hline foot per mile (ft/mi) & 0.1894 & meter per kilometer $(\mathrm{m} / \mathrm{km})$ \\
\hline \multicolumn{3}{|c|}{ Transmissivity* } \\
\hline foot squared per day $\left(\mathrm{ft}^{2} / \mathrm{d}\right)$ & 0.09290 & meter squared per day $\left(\mathrm{m}^{2} / \mathrm{d}\right)$ \\
\hline
\end{tabular}

Temperature in degrees Celsius $\left({ }^{\circ} \mathrm{C}\right)$ may be converted to degrees Fahrenheit $\left({ }^{\circ} \mathrm{F}\right)$ as follows:

$$
{ }^{\circ} \mathrm{F}=\left(1.8 x^{\circ} \mathrm{C}\right)+32 .
$$

Specific conductance is given in microsiemens per centimeter at 25 degrees Celsius $(\mu \mathrm{S} / \mathrm{cm}$ at $\left.25^{\circ} \mathrm{C}\right)$.

Concentrations of chemical constituents in water are given either in milligrams per liter (mg/L) or micrograms per liter $(\mu \mathrm{g} / \mathrm{L})$.

*Transmissivity: The standard unit for transmissivity is cubic foot per day per square foot times foot of aquifer thickness [(ft $\left.\left.\mathrm{ft}^{3} / \mathrm{d}\right) / \mathrm{ft}^{2}\right] \mathrm{ft}$. In this report, the mathematically reduced form, foot squared per day $\left(\mathrm{ft}^{2} / \mathrm{d}\right)$, is used for convenience. 


\section{Conversion Factors, Datums, and Abbreviations and Acronyms-Continued}

\section{Datums}

Vertical coordinate information is referenced to the National Geodetic Vertical Datum of 1929 (NGVD 29).

Horizontal coordinate information is referenced to the North American Datum of 1927 (NAD 27).

Altitude, as used in this report, refers to distance above the vertical datum

\section{Abbreviations and Acronyms}

$\begin{array}{ll}\text { ATR Complex } & \begin{array}{l}\text { Advanced Test Reactor Complex (formerly RTC, Reactor Technology Complex; } \\ \text { and TRA, Test Reactor Area) }\end{array} \\ \text { BEA } & \text { Battelle Energy Alliance } \\ \text { BLS } & \text { below land surface } \\ \text { CFA } & \text { Central Facilities Area } \\ \text { DOE } & \text { U.S. Department of Energy } \\ \text { EMFM } & \text { electromagnetic flow meter } \\ \text { ESRP } & \text { eastern Snake River Plain } \\ \text { HO } & \text { core rod sizing } \\ \text { INL } & \text { Idaho National Laboratory } \\ \text { INTEC } & \text { Idaho Nuclear Technology and Engineering Center } \\ \text { IRL } & \text { interim reporting level } \\ \text { LT-MDL } & \text { long-term method detection level } \\ \text { LRL } & \text { laboratory reporting level } \\ \text { MFC } & \text { Materials and Fuels Complex } \\ \text { MRL } & \text { minimum reporting level } \\ \text { MSDS } & \text { material safety data sheets } \\ \text { N } & \text { nitrogen } \\ \text { NWOL } & \text { National Water Quality Laboratory (USGS) } \\ \text { P } & \text { phosphorus } \\ \text { RESL } & \text { Radiological and Environmental Sciences Laboratory (DOE) } \\ \text { RWMC } & \text { Radioactive Waste Management Complex } \\ S & \text { sample standard deviation } \\ \text { SS } & \text { stainless steel } \\ \text { TAN } & \text { Test Area North } \\ \text { TRA } & \text { Test Reactor Area } \\ \text { USGS } & \text { U.S. Geological Survey } \\ & \end{array}$





\title{
Completion Summary for Boreholes USGS 140 and USGS 141 near the Advanced Test Reactor Complex, Idaho National Laboratory, Idaho
}

\author{
By Brian V. Twining, Roy C. Bartholomay, and Mary K.V. Hodges
}

\section{Abstract}

In 2013, the U.S. Geological Survey, in cooperation with the U.S. Department of Energy, drilled and constructed boreholes USGS 140 and USGS 141 for stratigraphic framework analyses and long-term groundwater monitoring of the eastern Snake River Plain aquifer at the Idaho National Laboratory in southeast Idaho. Borehole USGS 140 initially was cored to collect continuous geologic data, and then re-drilled to complete construction as a monitor well. Borehole USGS 141 was drilled and constructed as a monitor well without coring. Boreholes USGS 140 and USGS 141 are separated by about 375 feet (ft) and have similar geologic layers and hydrologic characteristics based on geophysical and aquifer test data collected. The final construction for boreholes USGS 140 and USGS 141 required 6-inch (in.) diameter carbon-steel well casing and 5-in. diameter stainless-steel well screen; the screened monitoring interval was completed about $50 \mathrm{ft}$ into the eastern Snake River Plain aquifer, between 496 and $546 \mathrm{ft}$ below land surface (BLS) at both sites. Following construction and data collection, dedicated pumps and water-level access lines were placed to allow for aquifer testing, for collecting periodic water samples, and for measuring water levels.

Borehole USGS 140 was cored continuously, starting from land surface to a depth of $543 \mathrm{ft} \mathrm{BLS}$. Excluding surface sediment, recovery of basalt and sediment core at borehole USGS 140 was about 98 and 65 percent, respectively. Based on visual inspection of core and geophysical data, about 32 basalt flows and 4 sediment layers were collected from borehole USGS 140 between 34 and $543 \mathrm{ft}$ BLS. Basalt texture for borehole USGS 140 generally was described as aphanitic, phaneritic, and porphyritic; rubble zones and flow mold structure also were described in recovered core material. Sediment layers, starting near $163 \mathrm{ft}$ BLS, generally were composed of fine-grained sand and silt with a lesser amount of clay; however, between 223 and $228 \mathrm{ft}$ BLS, silt with gravel was described. Basalt flows generally ranged in thickness from 3 to $76 \mathrm{ft}$ (average of $14 \mathrm{ft}$ ) and varied from highly fractured to dense with high to low vesiculation.

Geophysical and borehole video logs were collected during certain stages of the drilling and construction process at boreholes USGS 140 and USGS 141. Geophysical logs were examined synergistically with the core material for borehole USGS 140; additionally, geophysical data were examined to confirm geologic and hydrologic similarities between boreholes USGS 140 and USGS 141 because core was not collected for borehole USGS 141. Geophysical data suggest the occurrence of fractured and (or) vesiculated basalt, dense basalt, and sediment layering in both the saturated and unsaturated zones in borehole USGS 141. Omni-directional density measurements were used to assess the completeness of the grout annular seal behind 6-in. diameter well casing. Furthermore, gyroscopic deviation measurements were used to measure horizontal and vertical displacement at all depths in boreholes USGS 140 and USGS 141.

Single-well aquifer tests were done following construction at wells USGS 140 and USGS 141 and data examined after the tests were used to provide estimates of specific-capacity, transmissivity, and hydraulic conductivity. The specific capacity, transmissivity, and hydraulic conductivity for well USGS 140 were estimated at 2,370 gallons per minute per foot $[(\mathrm{gal} / \mathrm{min}) / \mathrm{ft})]$, $4.06 \times 10^{5}$ feet squared per day $\left(\mathrm{ft}^{2} / \mathrm{d}\right)$, and 740 feet per day (ft/d), respectively. The specific capacity, transmissivity, and hydraulic conductivity for well USGS 141 were estimated at $470(\mathrm{gal} / \mathrm{min}) / \mathrm{ft}, 5.95 \times 10^{4} \mathrm{ft}^{2} / \mathrm{d}$, and $110 \mathrm{ft} / \mathrm{d}$, respectively. Measured flow rates remained relatively constant in well USGS 140 with averages of 23.9 and $23.7 \mathrm{gal} / \mathrm{min}$ during the first and second aquifer tests, respectively, and in well USGS 141 with an average of $23.4 \mathrm{gal} / \mathrm{min}$. 
Water samples were analyzed for cations, anions, metals, nutrients, volatile organic compounds, stable isotopes, and radionuclides. Water samples from both wells indicated that concentrations of tritium, sulfate, and chromium were affected by wastewater disposal practices at the Advanced Test Reactor Complex. Most constituents in water from wells USGS 140 and USGS 141 had concentrations similar to concentrations in well USGS 136, which is upgradient from wells USGS 140 and USGS 141.

\section{Introduction}

The U.S. Geological Survey (USGS), in cooperation with the U.S. Department of Energy (DOE), has collected borehole information at the Idaho National Laboratory (INL) since 1949 to provide baseline data concerning the migration and disposition of radiochemical and chemical wastes in the eastern Snake River Plain (ESRP) aquifer. The USGS is refining numerical models for the movement of groundwater and contaminants in the ESRP aquifer. Additional hydrogeologic and borehole information near the Advanced Test Reactor (ATR) Complex is needed to understand the effects of episodic surface-water flow from the Big Lost River in the area south of the ATR Complex (fig. 1). Hydrogeologic information about hydraulic properties is needed to define water movement as it relates to contaminant transport; furthermore, borehole information is necessary to better define stratigraphic layering and identify the general composition of sediment layers that control unsaturated groundwater flow. Additionally, the INL groundwater monitoring plan update (U.S. Department of Energy, 2003) suggested the need for additional monitor wells (screened in the upper $50 \mathrm{ft}$ of the aquifer) downgradient from the ATR Complex (fig. 1) to better monitor radiochemical and chemical waste discharged to infiltration ponds at the ATR Complex (Davis, 2010).

On April 22, 2013, the USGS started core drilling borehole USGS 140 (fig. 2). Borehole USGS 140 was cored continuously from 0 to $17 \mathrm{ft}$ below land surface (BLS) and from 34 to $543 \mathrm{ft} \mathrm{BLS}$. From 0 to $17 \mathrm{ft} \mathrm{BLS}$, unsorted sand to cobble-sized material (Wentworth, 1922), with some clasts exceeding 4 in. in diameter, resulted in poor core recovery. At $17 \mathrm{ft}$ BLS, a decision was made to drive a 10-in. diameter surface casing to the uppermost basalt flow at $34 \mathrm{ft} \mathrm{BLS}$ to case through surficial sediment material after the coring equipment sustained damage. Starting on June 13, 2013, borehole USGS 140 was continuously cored from 34 to $543 \mathrm{ft}$ BLS. Core drilling continued for 11 days to a depth of $483 \mathrm{ft}$ BLS, stopping near the top of the ESRP aquifer to set permanent well casing and to prevent caving from the unsaturated zone.
Between 34 and $483 \mathrm{ft}$ BLS, borehole USGS 140 was reamed to an 8-in. diameter and 6-in. diameter casing was set; afterwards, annular seal was pumped in from land surface to seal the annular space between the casing and drill hole. Starting on June 26, 2013, core drilling resumed for 2 days from 483 to $543 \mathrm{ft} \mathrm{BLS}$; afterward, the borehole between 483 and $546 \mathrm{ft}$ BLS was reamed to a 6.1-in. diameter to accommodate a 5 -in. diameter well screen. Final construction of borehole USGS 140 was completed on July 15, 2013; afterward, a submersible pump and water-level access line were set to allow for aquifer testing and sampling. Two aquifer tests were completed between July 30 and 31, 2013, and water-quality samples were collected at the end of the second aquifer test on July 31, 2013.

On August 13, 2013, the USGS INL Project Office started drilling borehole USGS 141 (fig. 2). During August 14-19, 2013, after 10-in. diameter surface casing was driven to the uppermost basalt flow at $38 \mathrm{ft} \mathrm{BLS}$, borehole USGS 141 was drilled using an 8-in. diameter downhole hammer from 38 to $485 \mathrm{ft}$ BLS. After drilling, 6-in. diameter well casing was set and annular seal was pumped in from land surface to seal the annular space between the casing and drill hole. On August 28, 2013, drilling between 485 and $546 \mathrm{ft}$ BLS was restarted using a 6.1-in. diameter rotary tri-cone drill bit. Final construction for borehole USGS 141 was completed on September 3, 2013; afterward, a submersible pump and water-level access line were set to allow for aquifer testing and sampling. Aquifer testing occurred during September 24-25, 2013, and water-quality samples were collected toward the end of the aquifer test on September 25, 2013.

\section{Purpose and Scope}

The purpose of the study is to better define the hydrogeology in the southwestern part of the INL, specifically south of the ATR Complex. Geologic, geophysical, and aquifer test data were collected and analyzed to a depth of about $545 \mathrm{ft}$ BLS in order to determine lithologic and hydraulic properties. Additionally, water samples were used to provide water-quality data downgradient from the ATR Complex. This report presents results of the construction and (or) coring, geophysical logging, aquifer testing, and water sampling for boreholes USGS 140 and USGS 141. General lithologic descriptions of the drill core for borehole USGS 140 are provided and detailed descriptions are included in the appendixes. A comprehensive suite of water samples, collected for each well, was analyzed for inorganic, organic, stable isotopes, and radionuclide constituents, and results are presented. 


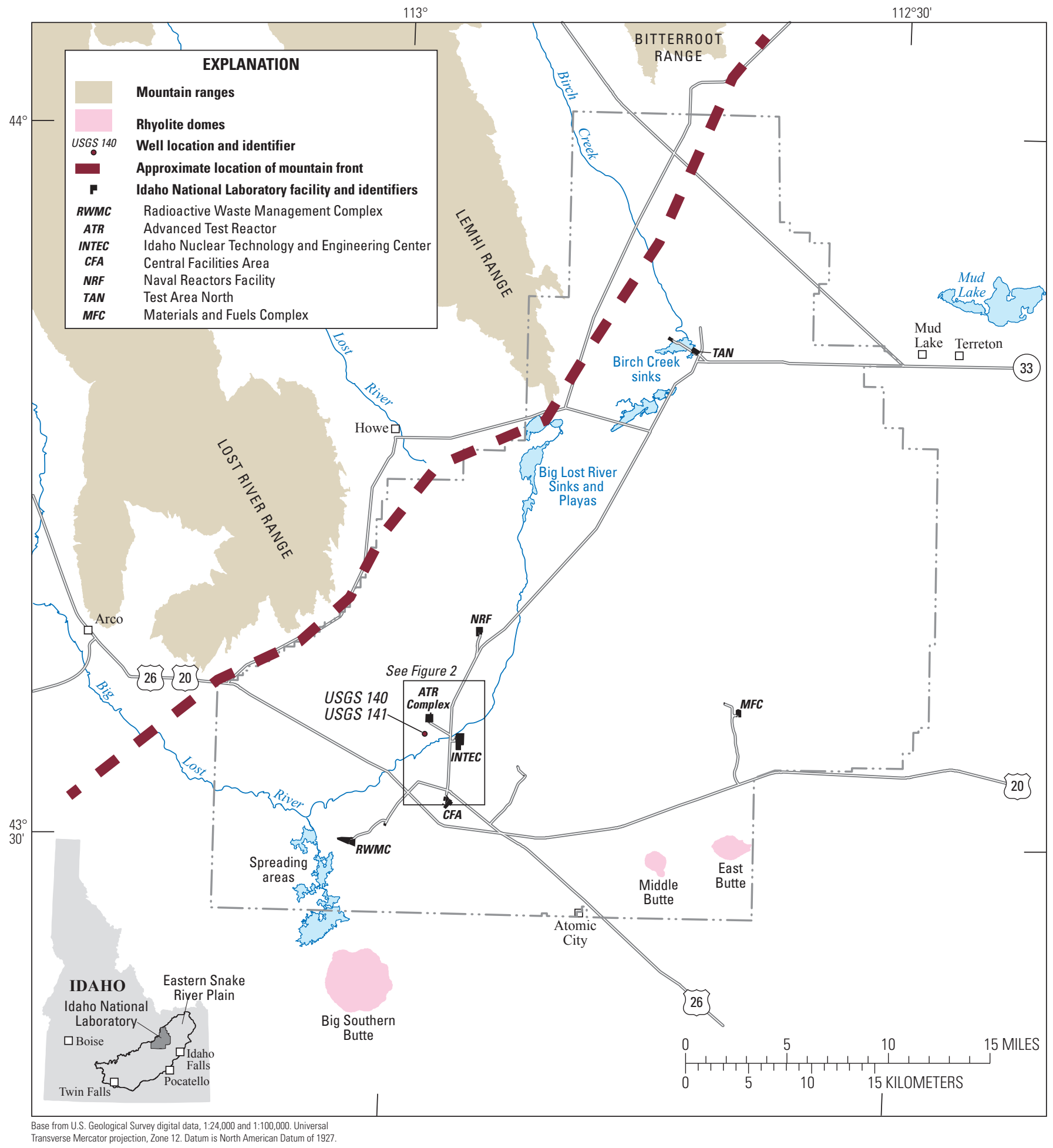

Figure 1. Location of selected facilities and boreholes USGS 140 and USGS 141, Idaho National Laboratory, Idaho. 


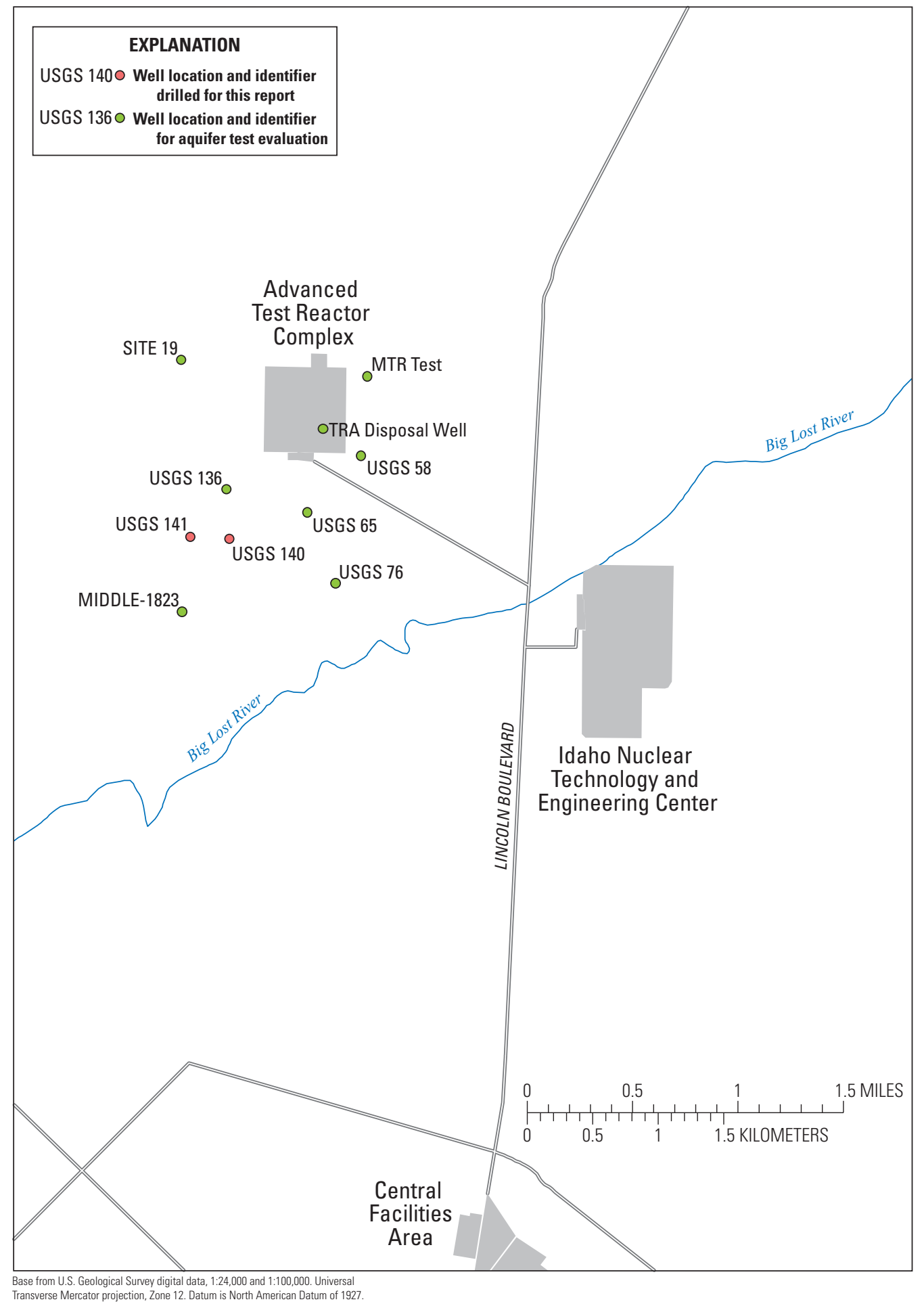

Figure 2. Location of boreholes USGS 140 and USGS 141 and selected monitor wells, Advanced Test Reactor Complex and vicinity, Idaho National Laboratory, Idaho. 


\section{Hydrogeologic Setting}

The INL is in the west-central part of the ESRP (fig. 1). The ESRP is a northeast-trending structural basin about $200 \mathrm{mi}$ long and 50-70 mi wide. Formation of the ESRP was caused by the passage of the North American tectonic plate over the Yellowstone Hot Spot (Pierce and Morgan, 1992). The ESRP is subject to continuing basaltic volcanism and subsidence because disruption to the crust resulted in increased heat flow (Blackwell and others, 1992) and emplacement of a dense, mid-crustal sill (Shervais and others, 2006). The subsiding ESRP basin was filled with interbedded terrestrial sediments and Pleistocene to late Pliocene basalt, 0.6 to 1.2 mi thick (Whitehead, 1992). The basaltic rocks and sedimentary deposits make up the ESRP aquifer.
The ESRP is composed mostly of olivine tholeiite basalt flows, which erupted as tube-fed, inflated, pahoehoe flows that make up more than 85 percent of the subsurface volume of the ESRP at the INL (Anderson and Liszewski, 1997). A diagram of a lobe of a tube-fed pahoehoe ESRP basalt flow, showing cooling fractures that develop perpendicular to the exterior surfaces, vesicle zones and sheets, pipe vesicles, interior mega vesicles, and a diktytaxitic to massive core, is presented in figure 3 . The distribution of basalt flows is controlled by topography, rate of effusion, and duration of eruption. Nearvent flows are thinner than distal flows, and accumulations of thin flows have a larger volume of high conductivity zones than the same volume of thick flows (Anderson and others, 1999).

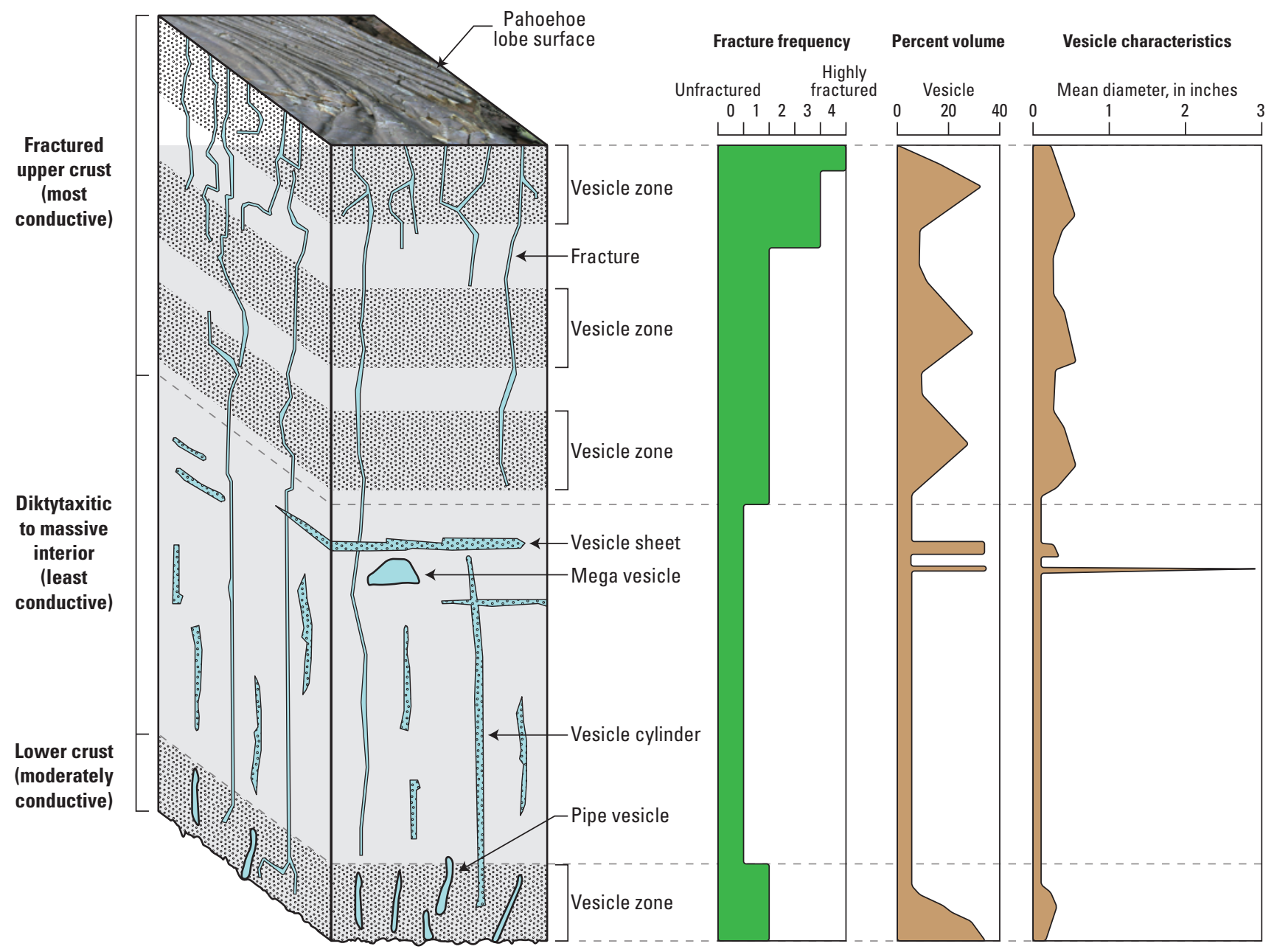

Figure 3. Idealized typical olivine tholeiite pahoehoe basalt flow (modified from Self and others, 1998, fig. 3, p. 90). The basalt flow is divided into three sections on the basis of vesicle characteristics and fracture frequency. Hydraulic conductivity is highest for the fractured upper crust, moderate for the lower crust, and lowest for the diktytaxitic to massive interior. The photograph of the pahoehoe lobe surface is courtesy of Scott Hughes, Emeritus Professor, Idaho State University, Pocatello, Idaho. 
The part of the Snake River Plain aquifer that underlies the ESRP is one of the most productive aquifers in the United States (U.S. Geological Survey, 1985, p. 193). Groundwater in the ESRP aquifer generally moves from northeast to southwest, eventually discharging to springs along the Snake River downstream of Twin Falls, Idaho-about $100 \mathrm{mi}$ southwest of the INL (Whitehead, 1992). Water moves through basalt fracture zones at the tops, bases, and sides of basalt flows. Infiltration of surface water, groundwater pumping, geologic conditions, and seasonal fluxes of recharge and discharge locally affect the movement of groundwater (Garabedian, 1986). Recharge to the ESRP aquifer primarily is from infiltration of applied irrigation water, streamflow, precipitation, and groundwater inflow from adjoining mountain drainage basins (Ackerman and others, 2006).

Throughout the INL, the March-May 2011 water-table altitude ranged from about 4,560 to 4,410 ft (Davis and others, 2013, fig. 9); at boreholes USGS 140 and USGS 141, the altitude of the water table is about 4,446 ft. Depth to water ranges from about $200 \mathrm{ft}$ BLS in the northern part of the INL to more than $900 \mathrm{ft} \mathrm{BLS}$ in the southeastern part; depth to water near the ATR Complex is about $490 \mathrm{ft} \mathrm{BLS}$. Most groundwater moves through the upper 200-800 ft of basaltic rocks (Mann, 1986, p. 21). The estimated transmissivity for the upper part of the ESRP aquifer is 1.1 to $760,000 \mathrm{ft}^{2} / \mathrm{d}$ reported by Ackerman (1991, p. 30) and Bartholomay and others (1997, table 3). The hydraulic gradient at the INL ranges from 2 to $10 \mathrm{ft} / \mathrm{mi}$; the average is about $4 \mathrm{ft} / \mathrm{mi}$ (Davis and others, 2013, fig. 9). Horizontal flow velocities of 2-20 ft/d have been calculated on the basis of the movement of various chemical and radiochemical constituents in different areas of the ESRP aquifer at the INL (Robertson and others, 1974; Mann and Beasley, 1994; Cecil and others, 2000; Busenberg and others, 2001). These flow rates equate to a travel time of about 70-700 years for water beneath the INL to travel to springs that discharge at the terminus of the ESRP aquifer near Twin Falls, Idaho (fig. 1). Localized tracer tests at the INL have shown vertical and horizontal transport rates as high as 60 and $150 \mathrm{ft} / \mathrm{d}$, respectively (Nimmo and others, 2002; Duke and others, 2007).

\section{Drilling and Borehole Construction Methods}

Drilling, well construction, and hydraulic testing by the USGS took place between April 22 and September 25, 2013. All activities were in accordance with the USGS INL Site Safety Plan and the INL Environmental Checklist requirements; additionally, the USGS performed and documented regular safety inspections and safety briefings.

Prior to drilling startup, protective tarps were placed under the drill rig, and equipment was checked on a daily basis for signs of hydraulic leaks. No reportable spills occurred while drilling boreholes USGS 140 or USGS 141. Additionally, flexible hose was run to well USGS 136 to supply drilling water used for coring, drilling, and well construction (fig. 2); about 38,000 gal of groundwater were used to core and construct boreholes USGS 140 and USGS 141.

\section{Boreholes USGS 140 and USGS 141—Drilling and Completion Methods}

Borehole USGS 140 was cored continuously using a Christensen $^{\mathrm{TM}} \mathrm{CS} 1500$ rotary drilling rig and HQ-size coring system, where HQ refers to core rod sizing (pipe size about 3.5-in. outside diameter and drill-bit size about 3.8-in. diameter). The coring system uses carbide and diamond core bits, core catchers, and latch assembly (fig. 4). Core was retrieved in 5-ft sections using a four-part wireline latching mechanism (quadlatch) at the top of the core-barrel assembly. After removal from the borehole, core was marked for orientation and depth in the field before boxing. Cores were photographed and archived at the INL Lithologic Core Storage Library (Davis and others, 1997), which is operated by the USGS at the Central Facilities Area (CFA) (fig. 1).

Drilling mud was used to support unsaturated-zone coring from 34 to $483 \mathrm{ft}$ BLS in borehole USGS 140. Drilling mud was selected to improve unsaturated-zone sediment recovery and to help stabilize sediment layers prone to caving. The general composition of the drilling mud was consistent with a bentonite gel that included groundwater (supplied from well USGS 136), Baroid Quik-gel ${ }^{\circledR}$, soda-ash, and Baroid EZ-Mud Gold ${ }^{\circledR}$. Material safety data sheets (MSDS) for the drilling mud components are included in appendix A. Drilling mud was mixed in a hopper and pumped into a 1,000-gal holding tank while circulating to maintain the mud product in solution; the $\mathrm{pH}$ and viscosity of the drilling mud were recorded for each new mixture. The $\mathrm{pH}$ of the drilling mud generally ranged from 7.8 to 8.5 , and the viscosity generally ranged from 35 to 50 seconds per quart. Drilling mud was injected continuously at rates that ranged from 10 to $16 \mathrm{gal} / \mathrm{min}$; about 30,000 gal of drilling mud was used to complete HQ-coring to $483 \mathrm{ft} \mathrm{BLS}$ in borehole USGS 140. While drilling borehole USGS 140, no re-circulation of drilling mud was observed below the first basalt fracture zone, near $56 \mathrm{ft}$ BLS.

Pressurized air and water were used to complete coring for borehole USGS 140 from 483 to $543 \mathrm{ft}$ BLS and to drill and construct boreholes USGS 140 and USGS 141. Water and air usage ranged from 2 to $7 \mathrm{gal} / \mathrm{min}$, with air pressures ranging from 100 to $350 \mathrm{lb} / \mathrm{in}^{2}$. About 8,000 gal of water was used to complete coring between 483 and $543 \mathrm{ft} \mathrm{BLS}$, to complete construction at borehole USGS 140, and to drill and construct borehole USGS 141.

Borehole USGS 141 was drilled from land surface to total completion depth using both downhole hammer and tri-cone rotary drill bits; no core samples were collected. Similar rotary drilling methods were used to complete construction for borehole USGS 140 after coring. Drilling, setting well casing, and setting well screen were performed using a $\mathrm{GEFCO}^{\mathrm{TM}} \mathrm{SD}-300$ drill rig; tri-cone and downhole hammer rotary bits were used to drill sections of the borehole prior to setting the casing and screen in boreholes USGS 140 and USGS 141. 


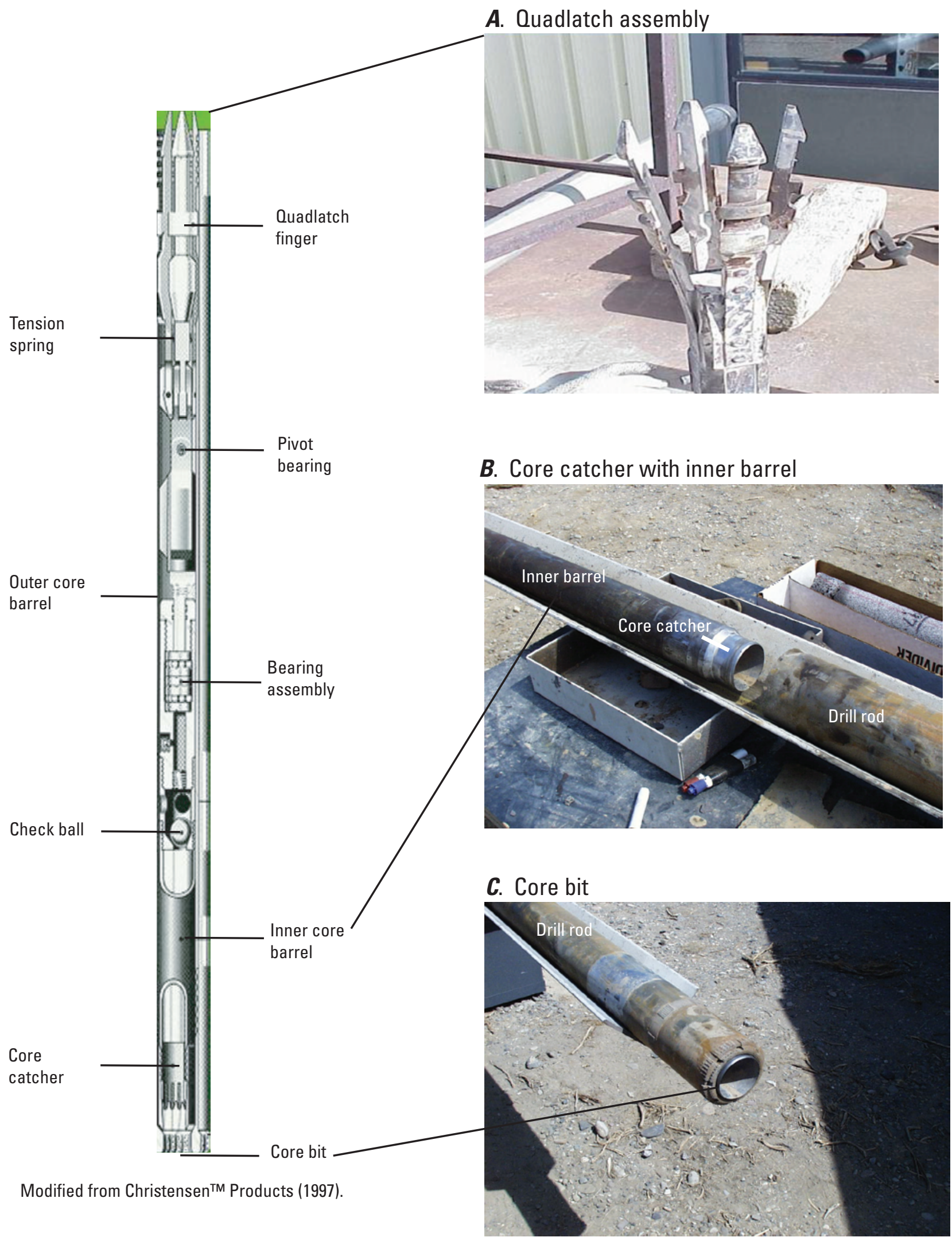

Figure 4. HO-size coring system similar to one used for coring borehole USGS 140, Idaho National Laboratory, Idaho. HO refers to core rod sizing (pipe size about 3.5-inch outside diameter and drill-bit size about 3.8-inch diameter). 
After drilling and setting 6-in. diameter casing, a grout annular seal was applied behind the casing using a mixture of water, Portland Type II cement, and bentonite (about 5 percent bentonite). The grout was mixed in holding tanks and pumped behind the casing using 1-in. diameter tremie pipe. Granular bentonite was poured from land surface to help fill large fractures at the discretion of the drill crew. Grout was mixed at the job site and pumped down the annular space until the grout slurry mixture reached land surface. About $50 \mathrm{ft}^{3}$ of grout was used to seal the annular space from land surface to about $483 \mathrm{ft}$ BLS in borehole USGS 140; about $64 \mathrm{ft}^{3}$ of grout was used to seal the annular space from land surface to about $485 \mathrm{ft}$ BLS in borehole USGS 141.

\section{Borehole USGS 140 Drilling Activity}

Core drilling started on April 22, 2013, at borehole USGS 140 with attempts to core surface sediment to the top of the first basalt contact. The recovery of sediment core between land surface and $17 \mathrm{ft}$ BLS was only partly successful because large cobbles ( $>4$-in. diameter) would not enter the core barrel. The USGS stopped surface sediment coring at about $17 \mathrm{ft}$ BLS when cobbles caused core barrel damage, which stopped drilling from progressing. Drilling activity was halted between April 23 and May 10, 2013.

On May 13, 2013, the GEFCO ${ }^{\text {TM }}$ SD-300 drill rig was mobilized and configured to drive 10 -in. diameter surface casing. The surface casing was drilled and driven to the first basalt contact, near $34 \mathrm{ft} \mathrm{BLS}$. To advance the casing through the gravel and sand surface sediment, a 10-in. diameter tri-cone bit was run in front of the casing along with a hydraulically operated casing driver mounted to the GEFCO ${ }^{\mathrm{TM}}$ SD-300 drill rig. When the surface casing encountered basalt, near $34 \mathrm{ft}$ BLS, the bit was removed and the Christensen ${ }^{\text {TM }}$ CS 1500 drill rig was brought back to restart HQ-coring.

Between May 14 and June 3, 2013, borehole USGS 140 was HQ-cored continuously from 34 to $483 \mathrm{ft}$ BLS. Basalt core was rinsed, dried, and marked for orientation and depth; sediment core was wrapped in plastic wrap and foil for preservation and marked for orientation and depth. Core recovery averaged $45 \mathrm{ft} / \mathrm{d}$; about 98 percent of basalt core and about 66 percent of sediment core was recovered between 34 and $483 \mathrm{ft} \mathrm{BLS}$. Missing intervals are identified on the core log presented in appendix B. On June 4, 2013, upon completion of coring, geophysical logs were collected prior to pulling the drill rod from the borehole. Because of unstable sediment layers, geophysical logs were not collected in the open borehole between 34 and $483 \mathrm{ft}$ BLS.

Between June 10 and 18, 2013, borehole USGS 140 was reamed to an 8-in. diameter using a rotary downhole hammer between 34 and $483 \mathrm{ft}$ BLS. While reaming, a failure in the injection pump resulted in a material collapse on the drill bit during drilling near $387 \mathrm{ft}$ BLS, which prevented the drill bit from advancing. Several hours were spent attempting to free the drill hammer, but efforts were unsuccessful. The USGS drilling team determined that the best approach would be to design, build, and advance a steel casing overshot tool. Three days later, the overshot tool successfully freed the downhole hammer. Drilling was restarted on June 18, 2013, and reaming was completed to $483 \mathrm{ft}$ BLS the same day.

For 3 days, starting on June 19, 2013, 6-in. diameter carbon steel well casing was welded and lowered down to $483 \mathrm{ft}$ BLS. The well casing did not advance past $470 \mathrm{ft}$ BLS while lowering and a 6-in. diameter tri-cone drill bit was lowered inside of the drill pipe to help advance the well casing between 470 and $483 \mathrm{ft}$ BLS. Once the 6-in. diameter well casing was set to $483 \mathrm{ft} \mathrm{BLS}, 50 \mathrm{ft}^{3}$ of grout was mixed and pumped down the annular space using a 1-in. diameter tremie line for 2 days, starting on June 24, 2013.

On June 26, 2013, HQ-coring was restarted for 2 days to complete coring in borehole USGS 140 between 483 and $543 \mathrm{ft}$ BLS. Core recovery averaged $27 \mathrm{ft} / \mathrm{d}$; about 99 percent of basalt core was recovered between 483 and $543 \mathrm{ft}$ BLS and sediment layers were not present between these depths. No coring took place between July 1 and 5, 2013. Geophysical logs were collected on July 8, 2013, prior to removal of the HQ-size drill rods.

Starting on July 10, 2013, a 6.1-in. diameter tungsten and carbide tri-cone drill bit was used to ream borehole USGS 140 from 483 to $546 \mathrm{ft}$ BLS. On July 11, 2013, after the drill bit and drill rods were removed, geophysical logs and borehole video logs were recorded between land surface and $546 \mathrm{ft}$ BLS. On July 15, 2013, a 5-in. diameter wire-wrap stainless steel (SS) screen was placed in borehole USGS 140 (fig. 5). A drill rod was used to lower the screen assembly to the bottom of the borehole on a reverse threaded casing adapter. Additional geophysical logs were collected on July 17 and 23, 2013; a borehole video log of the completed borehole USGS 140 was taken on July 22, 2013.

On July 24, 2013, borehole USGS 140 was configured with a Grundfos ${ }^{\mathrm{TM}}$ 5-horsepower SS submersible pump, 4-wire (7 gauge) pump wire, 1.25-in. diameter SS discharge line, and 1-in. diameter SS water-level line (fig. 5). The submersible pump intake was set near $526 \mathrm{ft}$ BLS, and the 1-in. diameter measuring line was extended down to $521 \mathrm{ft} \mathrm{BLS}$. The final construction of borehole USGS 140 (fig. 5) includes (1) 10-in. diameter carbon steel casing extending from land surface to $34 \mathrm{ft} \mathrm{BLS}$, (2) 6-in. diameter carbon steel casing extending from $2 \mathrm{ft}$ above land surface to $483 \mathrm{ft}$ BLS, (3) figure k-packer with 6 -in. diameter rubber sealing wipers by 5 -in. pipe size diameter from 475 to $476 \mathrm{ft} \mathrm{BLS,} \mathrm{(4)} \mathrm{5-in.} \mathrm{diameter} 304 \mathrm{SS}$ screen blank extending from 476 to $496 \mathrm{ft} \mathrm{BLS}$, and (5) 5-in. diameter 304 SS wire-wrap well screen (0.020-in. slot) equipped with a screen bottom cap extending from 496 to $546 \mathrm{ft}$ BLS (fig. 5; table 1). Surface completion includes a 4-ft diameter concrete pad complete with a brass survey marker, and a locking wellhead. 
USGS 140

Site identifier: 433441112581201

Land surface altitude at marker: 4,936.51 ft (NGVD 29)

Note:

$\mathrm{ft}$ BLS - feet below land surface

in. - inch

NGVD 29 - National Geodetic Vertical Datum of 1929

USGS - U.S. Geological Survey

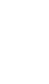
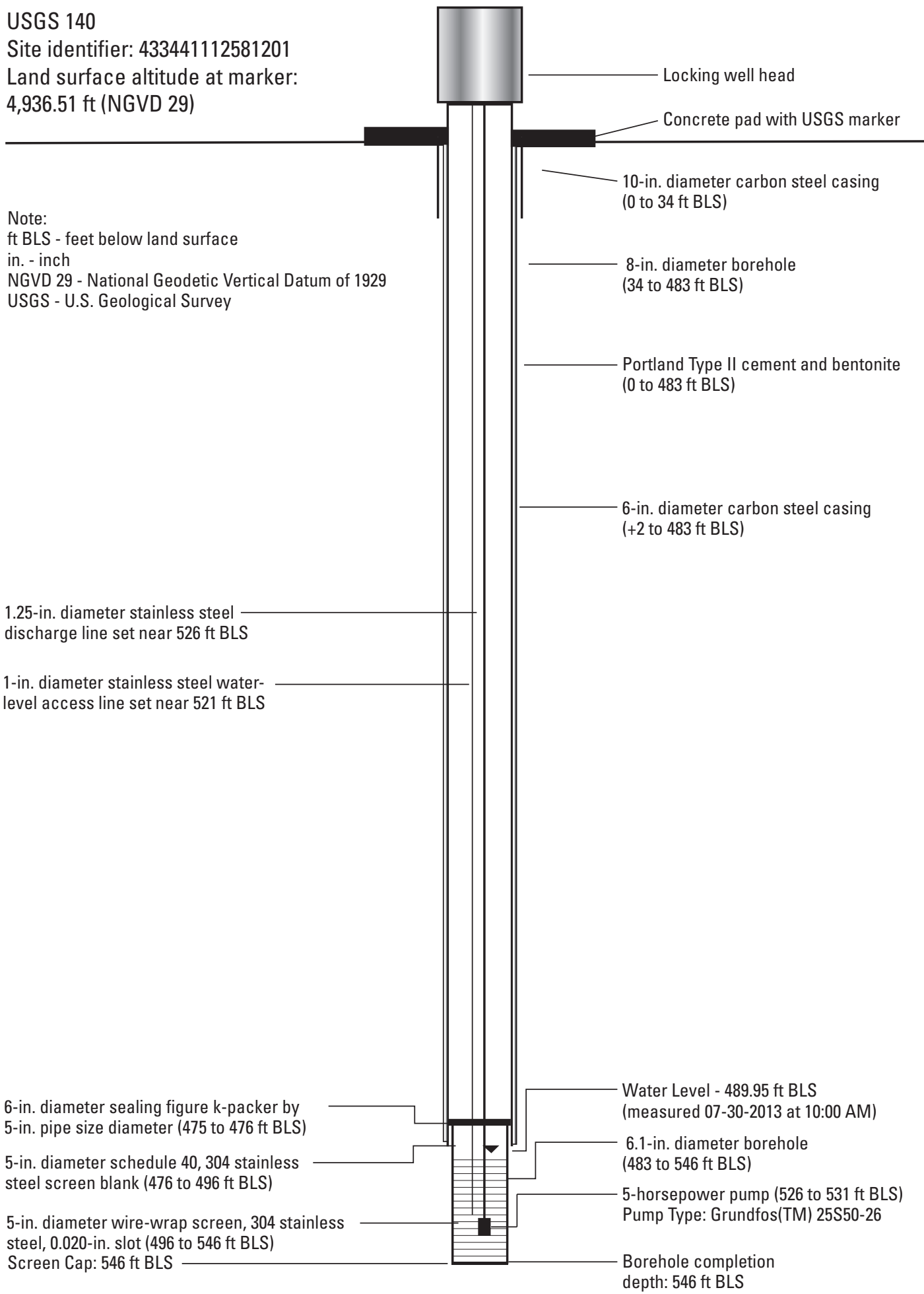
Table 1. Location and construction information for boreholes USGS 140 and USGS 141, Advanced Test Reactor Complex, Idaho National Laboratory, Idaho.

[Local name: Local well identifier used in this study. Locations of well are shown in figures 1 and 2 . Site identifier: Unique numerical identifier used to access well data (http://waterdata.usgs.gov/nwis). Aquifer thickness: Aquifer base estimated from well MIDDLE-1823 (ig. 2), near 1,040 ft BLS (Helm-Clark and others, 2005). Borehole diameter: Based on drilled diameter of screened interval. Deviation correction: Reported at $490 \mathrm{ft}$ BLS and taken from Century ${ }^{\mathrm{TM}}$ tool number 9095 gryroscopic survey results. Abbreviations: NAD 27, North American Datum of 1927; NGVD 29, National Geodetic Vertical Datum of 1929; BLS, below land surface; ft, foot; in., inch]

\begin{tabular}{|c|c|c|}
\hline Local name & USGS 140 & USGS 141 \\
\hline Longitude & $112^{\circ} 58^{\prime} 11.99^{\prime \prime}(\mathrm{NAD} 27)$ & $112^{\circ} 58^{\prime} 16.31^{\prime \prime}(\mathrm{NAD} 27)$ \\
\hline Measurement point elevation & 4,936.51 ft (NGVD 29) & 4,938.20 ft (NGVD 29) \\
\hline Aquifer thickness & $550 \mathrm{ft}$ & $550 \mathrm{ft}$ \\
\hline Completion depth & $546 \mathrm{ft}$ BLS & $546 \mathrm{ft}$ BLS \\
\hline Well screen slot size & 20 -slot (0.020-in. openings) & 20 -slot (0.020-in. openings) \\
\hline Top of screen & $496 \mathrm{ft}$ BLS & $496 \mathrm{ft}$ BLS \\
\hline Bottom of screen & $546 \mathrm{ft}$ BLS & $546 \mathrm{ft}$ BLS \\
\hline Deviation correction & $-0.26 \mathrm{ft}$ & $0.0 \mathrm{ft}$ \\
\hline Depth to water & $\begin{array}{l}489.95 \mathrm{ft} \text { BLS, measured July 30, } 2013 \\
\text { at 10:00 a.m. }\end{array}$ & $\begin{array}{l}492.18 \mathrm{ft} \mathrm{BLS} \text {, measured September 24, } 2013 \\
\text { at 08:59 a.m. }\end{array}$ \\
\hline
\end{tabular}

\section{Borehole USGS 141 Drilling Activity}

Starting on August 13, 2013, equipment was mobilized to begin drilling borehole USGS 141 after clearances were obtained. On August 14, 2013, 10-in. diameter surface casing was driven to the top of the first basalt contact near $38 \mathrm{ft}$ BLS. To advance the casing through the gravel and sand surface sediment, a 10-in. diameter tri-cone bit was run in front of the casing along with a hydraulically operated casing driver mounted to the $\mathrm{GEFCO}^{\mathrm{TM}} \mathrm{SD}-300$ drill rig. Once surface casing met basalt, the bit was removed and the $\mathrm{GEFCO}^{\mathrm{TM}}$ SD-300 was reconfigured to start drilling.

From August 15 to 19, 2013, borehole USGS 141 was drilled using an 8-in. diameter downhole hammer between 38 and $485 \mathrm{ft}$ BLS. The downhole hammer penetrated quickly through the basalt and sediment and the drill bit was removed on August 19, 2013. On August 20, 2013, a borehole video log showed that borehole USGS 141 was open to $472 \mathrm{ft} \mathrm{BLS}$.

Starting on August 21, 2013, 20-ft sections of 6-in. diameter carbon steel well casing were welded and lowered down to $485 \mathrm{ft}$ BLS. The well casing was advanced to $484 \mathrm{ft}$ BLS; however, to get the well casing to the bottom, a 6-in. diameter tri-cone drill bit was lowered inside of the drill pipe to advance the 6-in. diameter well casing to $485 \mathrm{ft} \mathrm{BLS}$. On August 22, 2013, after the well casing was set to bottom, geophysical logs were collected through the casing. Afterward, $63 \mathrm{ft}^{3}$ of grout was mixed and pumped down the annular space using a 1-in. diameter tremie line for 3 days starting on August 22, 2013.
On August 28, 2013, a 6.1-in. diameter tungsten and carbide tri-cone drill bit was used to drill borehole USGS 141 from 485 to $546 \mathrm{ft}$ BLS. On August 29 and September 3, 2013, after the tri-cone drill bit was removed, geophysical logs and borehole video logs were collected between 485 and $546 \mathrm{ft}$ BLS and indicated no obstructions. On September 3, 2013, after video confirmation, the 5 -in. diameter wire-wrap SS screen was placed in borehole USGS 141 (fig. 6). A drill rod was used to lower the screen assembly to the bottom of the borehole on a reverse threaded casing adapter. On September 10, 2013, after the drill rod was removed, a final borehole video log was recorded to examine the condition of the casing and well screen. Additional geophysical logs were collected on September 11 and 16, 2013.

On September 17, 2013, borehole USGS 141 was configured with a Grundfos ${ }^{\mathrm{TM}} 5$-horsepower SS submersible pump, 4-wire (7 gauge) pump wire, 1.25-in. diameter SS discharge line, and 1-in. diameter SS water-level line (fig. 6). The submersible pump intake was set near $526 \mathrm{ft} \mathrm{BLS}$, and the 1-in. diameter measuring line was extended down to $521 \mathrm{ft} \mathrm{BLS}$. The final construction of borehole USGS 141 (fig. 6) includes (1) 10-in. diameter steel casing extending from land surface to $38 \mathrm{ft} \mathrm{BLS}$; (2) 6-in. diameter steel casing extending from $2 \mathrm{ft}$ above land surface to $485 \mathrm{ft}$ BLS; (3) figure k-packer with 6 -in. diameter rubber sealing wipers by 5 -in. pipe size diameter from 475 to $476 \mathrm{ft} \mathrm{BLS}$; (4) 5-in. diameter 304 SS casing blank extending from 476 to $496 \mathrm{ft} \mathrm{BLS}$; and (5) 5-in. diameter 304 SS wire-wrap well screen (0.020 in. slot) equipped with a screen bottom cap extending from 496 to $546 \mathrm{ft}$ BLS (fig. 6). Surface completion includes a 4-ft diameter concrete pad complete with a brass survey marker and a locking wellhead. 
USGS 141

Site identifier: 433441112581601

Land surface altitude at marker: 4,938.20 ft (NGVD 29)

Note:

$\mathrm{ft}$ BLS - feet below land surface

in. - inch

NGVD 29 - National Geodetic Vertical

Datum of 1929

USGS - U.S. Geological Survey

25-in. diameter stainless steel

discharge line set near $526 \mathrm{ft} \mathrm{BLS}$

1 -in. diameter stainless steel

water-level access line set

near $521 \mathrm{ft}$ BLS

5-in. pipe size diameter (475 to $476 \mathrm{ft} \mathrm{BLS}$ )

5-in. diameter schedule 40, 304 stainless steel screen blank (476 to $496 \mathrm{ft} \mathrm{BLS}$ )

5-in. diameter wire-wrap screen, 304 stainless steel, 0.020 -in. slot (496 to $546 \mathrm{ft}$ BLS)

Screen Cap: $546 \mathrm{ft}$ BLS

Borehole completion
depth: $546 \mathrm{ft}$ BLS

Water Level - 492.18 ft BLS (measured 09-24-2013 at 08:59 AM)

6.1 -in. diameter borehole (485 to $546 \mathrm{ft} \mathrm{BLS}$ )

5-horsepower pump (526 to $531 \mathrm{ft} \mathrm{BLS)}$

Pump Type: Grundfos 25S50-26
Depth (ft BLS)

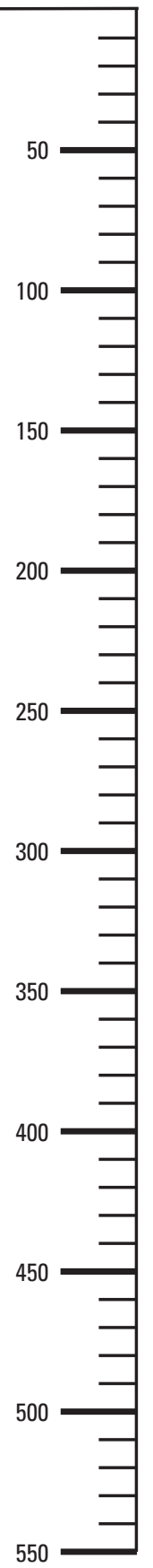

Figure 6. Final constructed borehole USGS 141, Advanced Test Reactor Complex, Idaho National Laboratory, Idaho. 


\section{Geologic and Geophysical Data}

Geologic data were collected and analyzed from core material to provide rock and sediment properties for borehole USGS 140; additionally, geologic and hydrologic data, including geologic contacts, were interpreted from geophysical logs collected and analyzed for boreholes USGS 140 and USGS 141. Geophysical logs provide a complete and continuous formation representation adjacent to the well bore and offer more consistency when selecting depths for geologic contacts, when core recovery is sometimes incomplete and subject to damage during the drilling. Boreholes USGS 140 and USGS 141 were drilled about $375 \mathrm{ft}$ apart (fig. 2) and have similar geologic features, as interpreted from geophysical logs. Core from borehole USGS 140 was photographed and labeled to provide detailed lithologic descriptions from 0 to $543 \mathrm{ft}$ BLS. Core photographs and lithologic logs are presented in appendix B.

The geophysical logging equipment operated by the USGS in boreholes USGS 140 and USGS 141 provided a select suite of conventional geophysical logs; additionally, borehole video logs were recorded to evaluate the condition of the boreholes after drilling and after final construction. Geophysical logs included natural gamma, neutron, caliper, gamma-gamma dual density, and electromagnetic flow meter (EMFM) logs. Additionally, gyroscopic deviation surveys were collected to determine the direction and magnitude of borehole deviation after the boreholes were completed. Geophysical logs, except EMFM station measurements, were collected and saved as electronic files in the form of physical measurement and depth at $0.1-\mathrm{ft}$ depth intervals. EMFM station data were collected at discrete depth locations in the screened borehole between 496 and $546 \mathrm{ft}$ BLS in boreholes USGS 140 and USGS 141. Geophysical and borehole video logs were collected during various phases of the drilling process. Using WellCAD ${ }^{\mathrm{TM}}$ software, a synergistic approach was used to display geophysical data and to determine geologic and hydrologic characteristics from these data. A summary of the geophysical and video log data is presented in table 2. Raw geophysical data are available upon request through the USGS INL Project Office.

\section{Geology}

The land surface at boreholes USGS 140 and USGS 141 is sparsely vegetated loess. From land surface to the top of the uppermost basalt flow in both boreholes, surficial materials include (1) loess exposed at the surface; (2) about $30 \mathrm{ft}$ of sand, gravel, and cobble material; and (3) about 1-2 ft of fine sand mixed with silt and clay just above the uppermost basalt contact at about 34 and $38 \mathrm{ft} \mathrm{BLS} \mathrm{in} \mathrm{boreholes} \mathrm{USGS} 140$ and USGS 141, respectively. Sediment was described from HQ-cores, driller notes, and sediment returns observed while driving 10-in. diameter surface casing to the top of the uppermost basalt flow (fig. 7 and appendix B).

Excluding surficial sediment, four sediment layers were described from 34 to $546 \mathrm{ft}$ BLS in borehole USGS 140 (fig. 7); five sediment layers were described from 38 to 546 $\mathrm{ft} \mathrm{BLS}$ in borehole USGS 141 (fig. 8). Where core material was not recovered, sediment layers were described from examination of geophysical and video logs. Including surficial sediment, sediment constitutes about 19 percent by volume (0-546 ft BLS) of boreholes USGS 140 and USGS 141. In borehole USGS 140, excluding surficial sediment, the thickness of the sediment layers ranged from 4 to $28 \mathrm{ft}$, whereas, in borehole USGS 141, excluding surficial sediment, the thickness of the sediment layers ranged from 2 to $27 \mathrm{ft}$. Sediment layers in both boreholes USGS 140 and USGS 141 appear to be similar in composition (mostly fine sand and silt with lesser amounts of clay and some gravel), thickness, and depth at which they occur.

Upon inspection of core and geophysical data, about 32 basalt flows were observed in borehole USGS 140 (fig.7 and appendix B). Basalt texture for borehole USGS 140 generally was aphanitic, phaneritic, diktytaxitic, and porphyritic. The basalt mostly is medium to dark gray in color. Rubble zones and flow mold structure also were described in recovered core material. Basalt flows in borehole USGS 140 ranged in thickness from 3 to $76 \mathrm{ft}$ (average $14 \mathrm{ft}$ ) and varied from highly fractured to dense, with high to low vesiculation. Detailed core descriptions and photographs, from 34 to $543 \mathrm{ft}$ BLS, are included in appendix B.

\section{Geophysical Logs}

Geophysical data were collected using Century Geophysical Corporation ${ }^{\mathrm{TM}}$ logging equipment, and the resulting data files were processed using WellCAD ${ }^{\mathrm{TM}}$ analytical software. Borehole video logs were recorded using one of two cameras: a Laval Underground Surveys ${ }^{\mathrm{TM}} \mathrm{R}-2000$ downhole color camera system or an Aries ${ }^{\mathrm{TM}}$ Industry WC-1750 downhole color camera. The USGS calibrates geophysical logging equipment annually using modified procedures established by Century ${ }^{\mathrm{TM}}$ Geophysical Corporation; sensor uncertainty is specified in table 2 . 


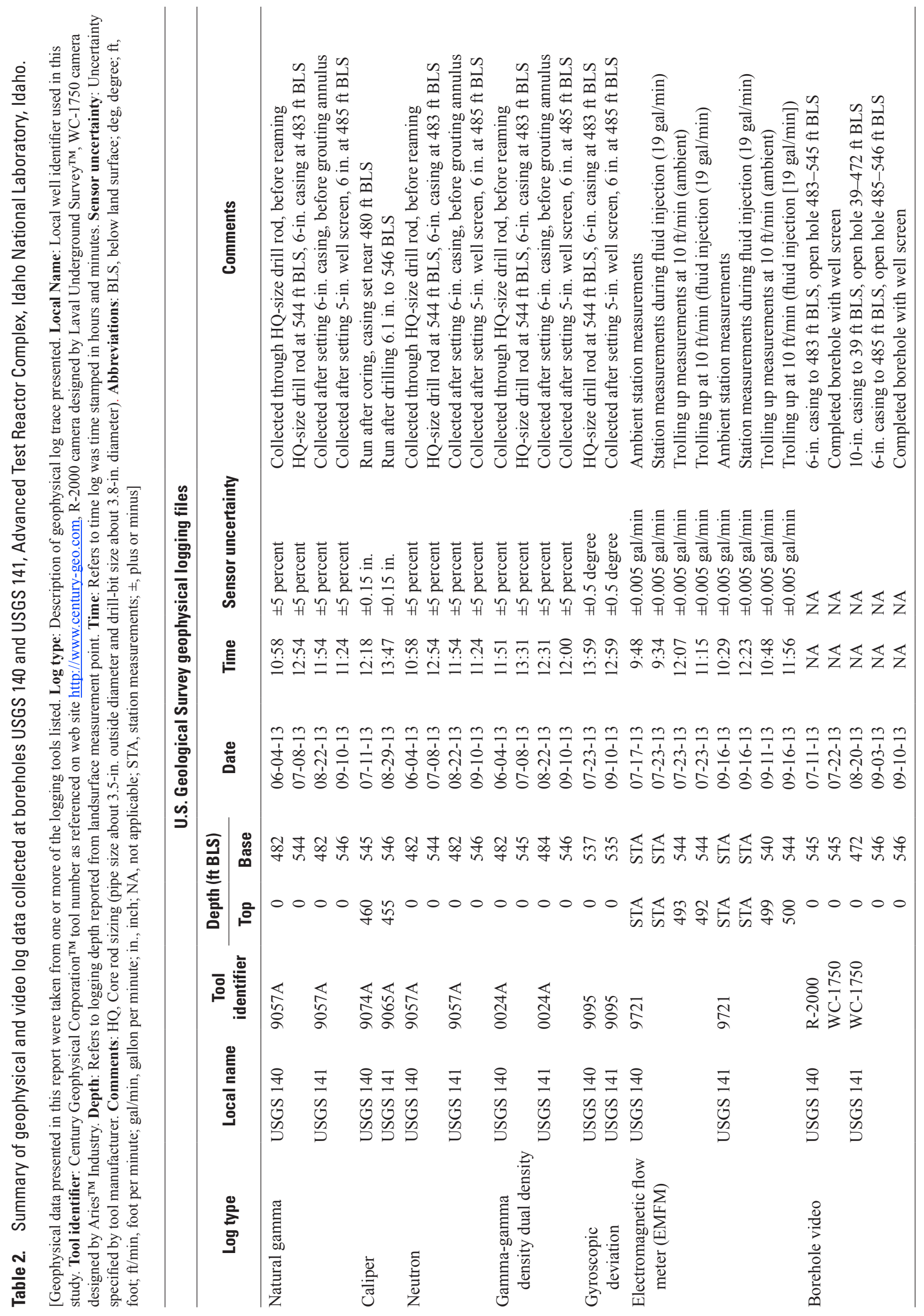




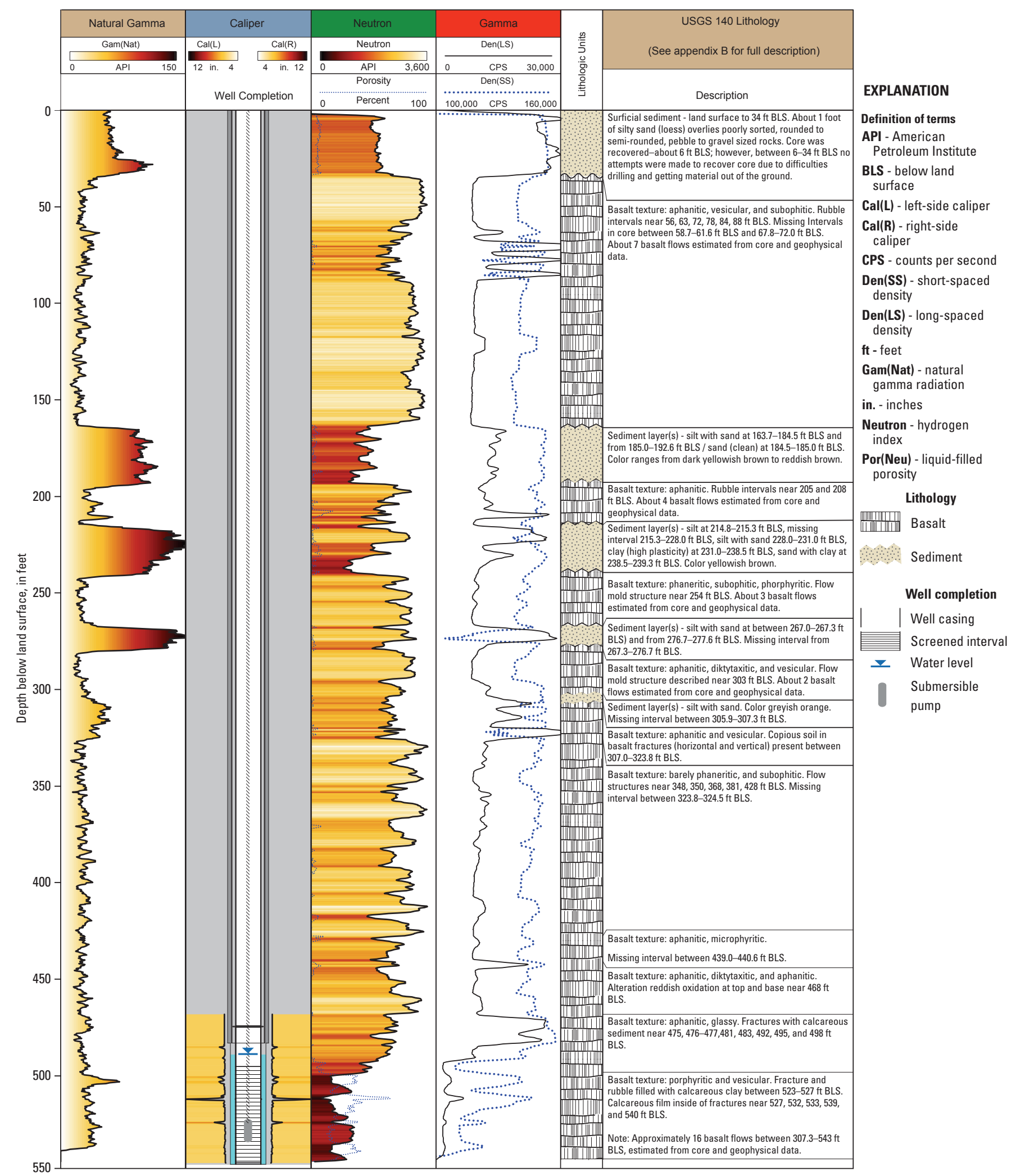

Figure 7. Geophysical and lithologic logs run from total depth to land surface and lithologic logs described from cores, video logs, and geophysical logs for borehole USGS 140, Advanced Test Reactor Complex, Idaho National Laboratory, Idaho. 


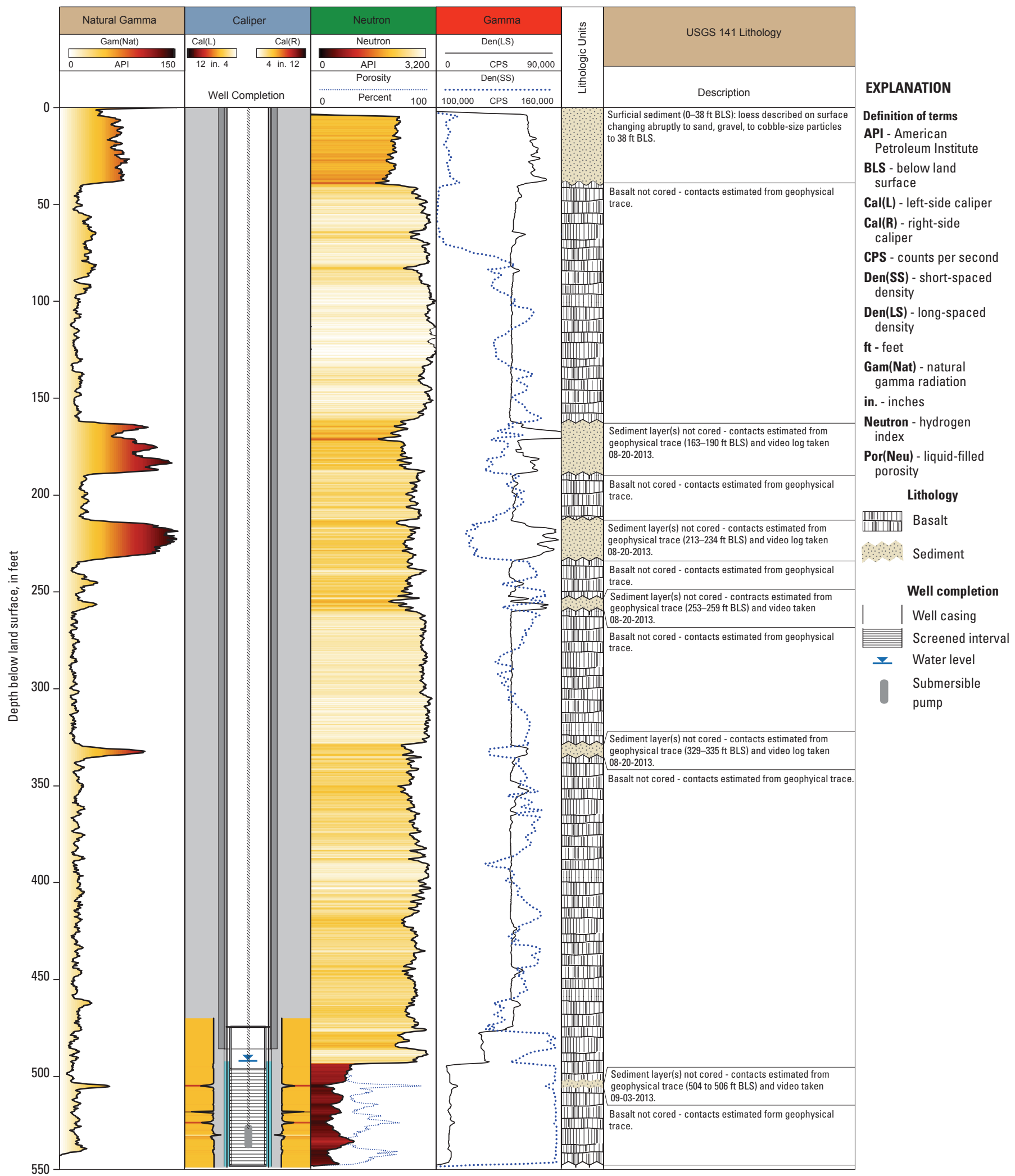

Figure 8. Geophysical and lithologic logs run from total depth to land surface for borehole USGS 141, Advanced Test Reactor Complex, Idaho National Laboratory, Idaho. 
Wireline geophysical logs and borehole video logs were collected at multiple stages during drilling and construction of boreholes USGS 140 and USGS 141 (ig. 9). Generally, logs were made under cased conditions to avoid tool damage owing to material collapse from rubble zones and sediment layers. Geophysical log data collected during stage 1 were merged with geophysical log data collected during stages 2 and 4 in boreholes USGS 140 and USGS 141, respectively.
The merged geophysical data represent a continuous profile where geophysical data were collected at different times. A composite of natural gamma, caliper, neutron, and gamma-gamma dual density logs and general lithology from land surface to completion depth near $546 \mathrm{ft}$ BLS are shown in figures 7 and $\underline{8}$. Attempts were made to describe the condition and drilled diameter of the borehole during each logging stage below:

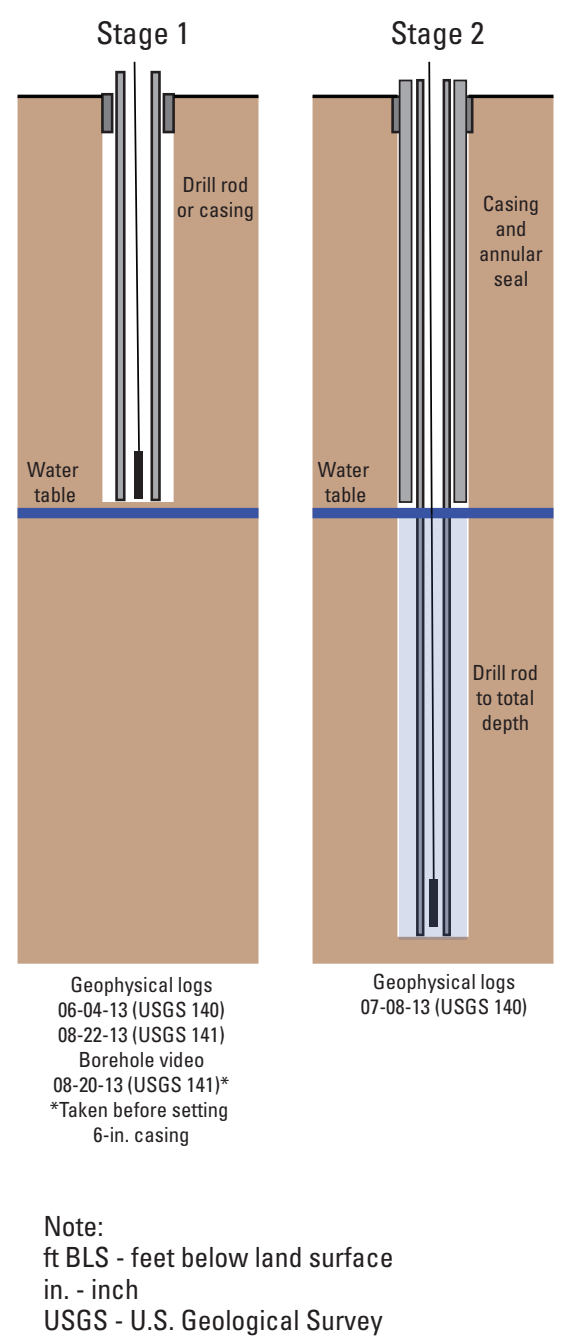

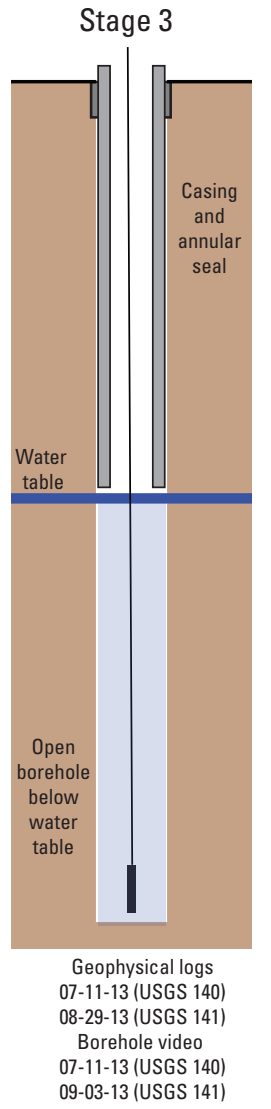

Not to scale

Figure 9. Borehole conditions during four stages of geophysical logging at boreholes USGS 140 and USGS 141, Advanced Test Reactor Complex, Idaho National Laboratory, Idaho.

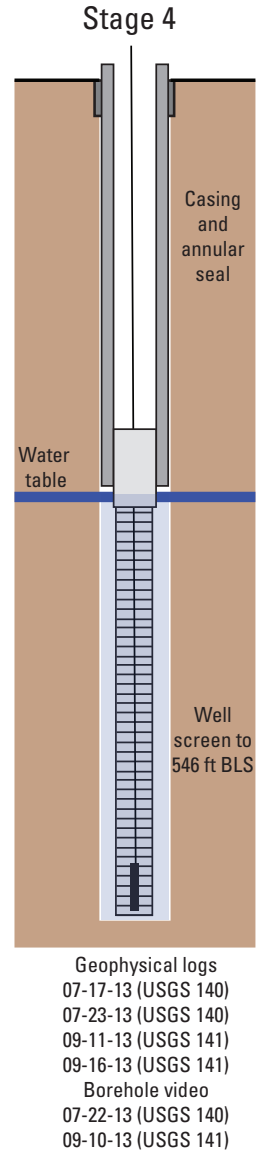

Stage 1. In borehole USGS 140, geophysical logs were collected after HQ-core drilling through the drill rod from land surface to $483 \mathrm{ft} \mathrm{BLS}$, where the drilled diameter was 3.8 in. In borehole USGS 141, geophysical logs were collected through 6-in. diameter casing from land surface to $485 \mathrm{ft}$ BLS before placing annular seal, where the drilled borehole diameter was $8.0 \mathrm{in}$.

Stage 2. Geophysical logs were collected after drilling to completion depth; logs were collected through the HQ-size drill rod in borehole USGS 140, where the drilled borehole diameter was 3.8 in. between 483 and $543 \mathrm{ft}$ BLS. During stage 2, 6-in. diameter well casing and annular seal extended from land surface to $483 \mathrm{ft} \mathrm{BLS}$. No geophysical logs were collected for borehole USGS 141.

Stage 3. Geophysical and video logs were collected for the open boreholes after drill rods were removed. The open-borehole diameter for boreholes USGS 140 and USGS 141 was 6.1-in.

Stage 4. Geophysical logs were collected after final construction of boreholes USGS 140 and USGS 141 (figs. 5 and $\underline{6}$ ). 


\section{Natural Gamma Logs}

Natural gamma logs record gamma radiation emitted by naturally occurring radioisotopes. The USGS uses these logs at the INL to identify sedimentary layers in boreholes and to distinguish between basalt flows that contain different amounts of potassium-40. The natural gamma detector measures total gamma radiation without distinguishing between individual contributions of the various isotopes.

Natural gamma logs were collected during stages 1, 2, and 4 (figs. 7 and 8). Excluding surface sediment, the tops of sediment layers were reported at about 165, 215, 267, and $304 \mathrm{ft}$ BLS in borehole USGS 140 (appendix B), and at about 163, 213, 254, 329, and $504 \mathrm{ft}$ BLS in borehole USGS 141. A borehole video log was used to confirm the presence of a sediment layer near $504 \mathrm{ft} \mathrm{BLS}$ in borehole USGS 141. Borehole USGS 140 displays an increase in natural gamma response near $504 \mathrm{ft}$ BLS and core descriptions indicate that fractures are filled with calcareous clay near the same depth; however, no sediment layer was identified based on core and video data.

\section{Caliper Logs}

The caliper tool makes a continuous log of the drill-hole diameter by using three extendable, spring-loaded arms that press against the sides of the borehole and detect changes in the diameter as the tool is raised from the bottom of the borehole. The caliper tool can detect changes in borehole diameter greater than or equal to $0.15 \mathrm{in}$.

Open-hole caliper logs were collected during stage 3 (fig. 9), and were displayed between 480 and $545 \mathrm{ft}$ BLS in boreholes USGS 140 and USGS 141 (figs. 10 and 11). Caliper logs were used to confirm the presence of fractured and/or vesicular basalt, dense basalt, and sediment layers used to define the lithologic patterns presented in figures 10 and 11 ; however, emphasis on lithologic change was placed on the screened intervals between 496 and $546 \mathrm{ft}$ BLS. Fractured and/or vesicular zones, identified in caliper logs, correlate with elevated neutron porosity data and changes in density for borehole USGS 140 (fig. 10). In borehole USGS 141, not all fractured and vesicular zones correlate with elevated neutron porosity and (or) density variations, and some anomalous borehole diameter measurements were observed near 518 and $530 \mathrm{ft}$ BLS. Dense and fractured and (or) vesicular basalt make up about 56 and 44 percent, respectively, of the lithology in the screened interval (496-546 ft BLS) in borehole USGS 140. Dense basalt, fractured and (or) vesicular basalt, and sediment make up about 58,38 , and 4 percent, respectively, of the lithology in the screened interval (496-546 ft BLS) in borehole USGS 141. Groundwater flow is expected to occur more readily in the zones identified as either fractured and (or) vesicular basalt.

\section{Neutron Logs}

Neutron measurements are a general indicator of hydrogen content; when they are combined with natural gamma logs for sediment location, they can be used to identify perched groundwater zones in the unsaturated zone. The neutron log records the continuous measurement of the induced radiation produced by bombarding surrounding media (casing, formation, and fluid) with fast neutrons (energies greater than $10^{5}$ electron volts from a sealed neutron source, which collide with surrounding atomic nuclei until they are captured (Keys, 1990, section 5, p. 95). The neutron tool used by the USGS INL Project Office has an americium/ beryllium neutron source and a Helium-3 detector that counts slow (thermal) neutrons (those that have energies less than 0.025 electron volts).

Neutron logs were collected during stages 1,2 , and 4 (fig. 9). Review of the neutron data indicated no evidence of perched groundwater in the unsaturated zone (land surface to about $490 \mathrm{ft}$ BLS). Neutron logs were examined for the screened section of aquifer (496-546 ft BLS) to identify areas of high and low hydrogen content in boreholes USGS 140 and USGS 141 (figs. 10 and 11). A color gradient, ranging from red (higher hydrogen content) to white (lower hydrogen content), was applied to approximate the location of waterproducing zones in figures $7, \underline{8}, \underline{10}$, and $\underline{11}$. The neutron log shows good agreement with HQ-core collected from borehole USGS 140 (fig. 10), where areas of low hydrogen content correlate with areas of dense and massive basalt, and areas of high hydrogen content correlate with areas of fractured and vesicular basalt. On the basis of basalt-hydrogen correlations, neutron logs show evidence for fractured and vesicular basalt, indicative of more productive water-producing zones, within the screened intervals at these depths: (1) borehole USGS 140, depths 497-502, 507-518, 521-522, and 533-538 ft BLS; (2) borehole USGS 141, depths 506-509, 514-516, 520-526, and 537-544 ft BLS (figs. 10 and 11).

\section{Gamma-Gamma Dual Density Logs}

The principle behind density logging is the detection of Compton-scattered gamma rays that originate from a small radioactive source. The intensity of the gamma radiation reflected back to the probe is primarily a function of electron density of the media after it is backscattered or absorbed in a drill hole, borehole fluid, or surrounding media. The type of density probe used for this investigation is the omnidirectional, dual detector sonde that responds to density variation in counts per second (CPS), registering higher CPS counts for lower density material. 


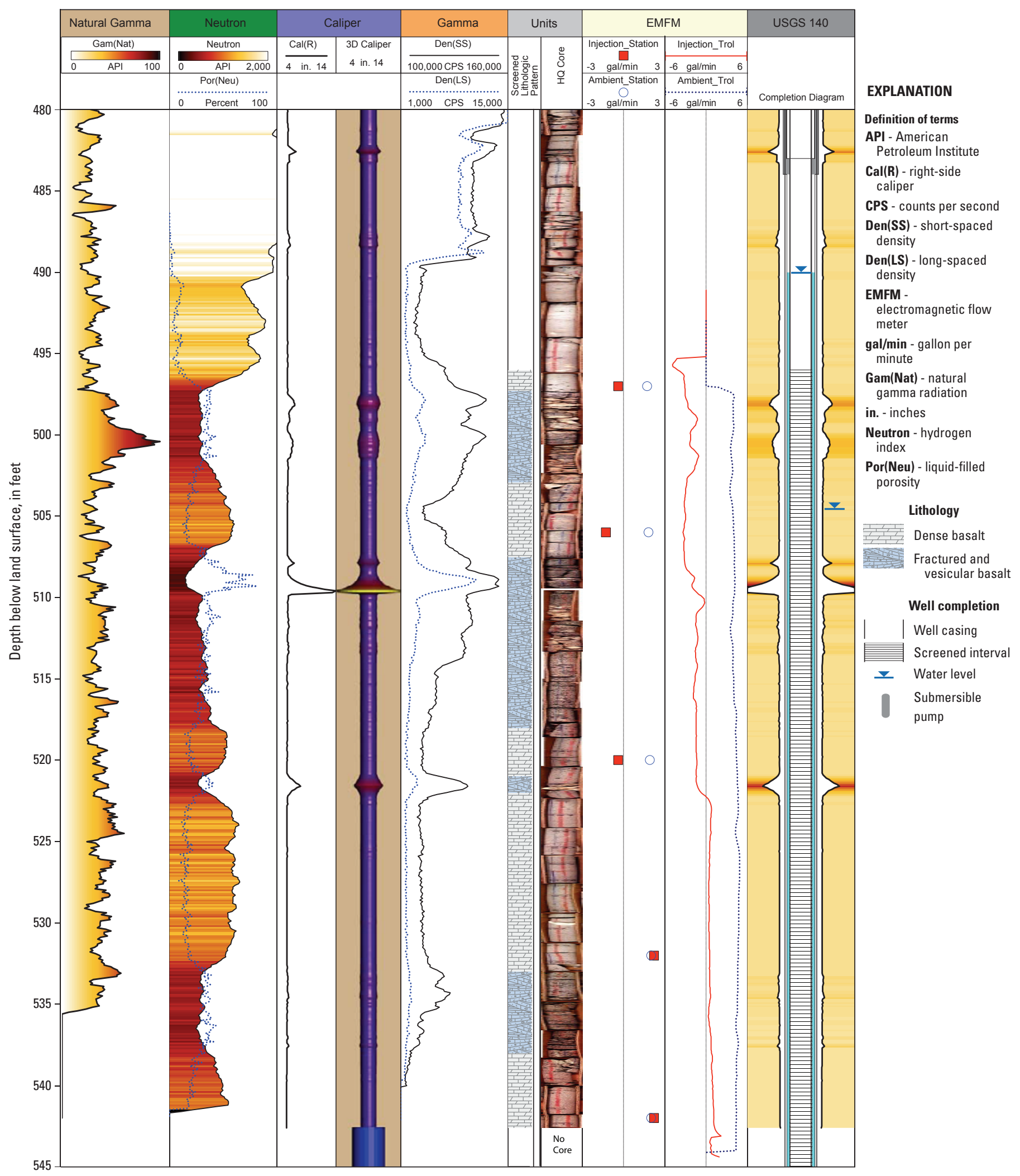

Figure 10. Expanded geophysical and lithologic logs with focus on depths $480-545$ feet below land surface for borehole USGS 140, Advanced Test Reactor Complex, Idaho National Laboratory, Idaho. 


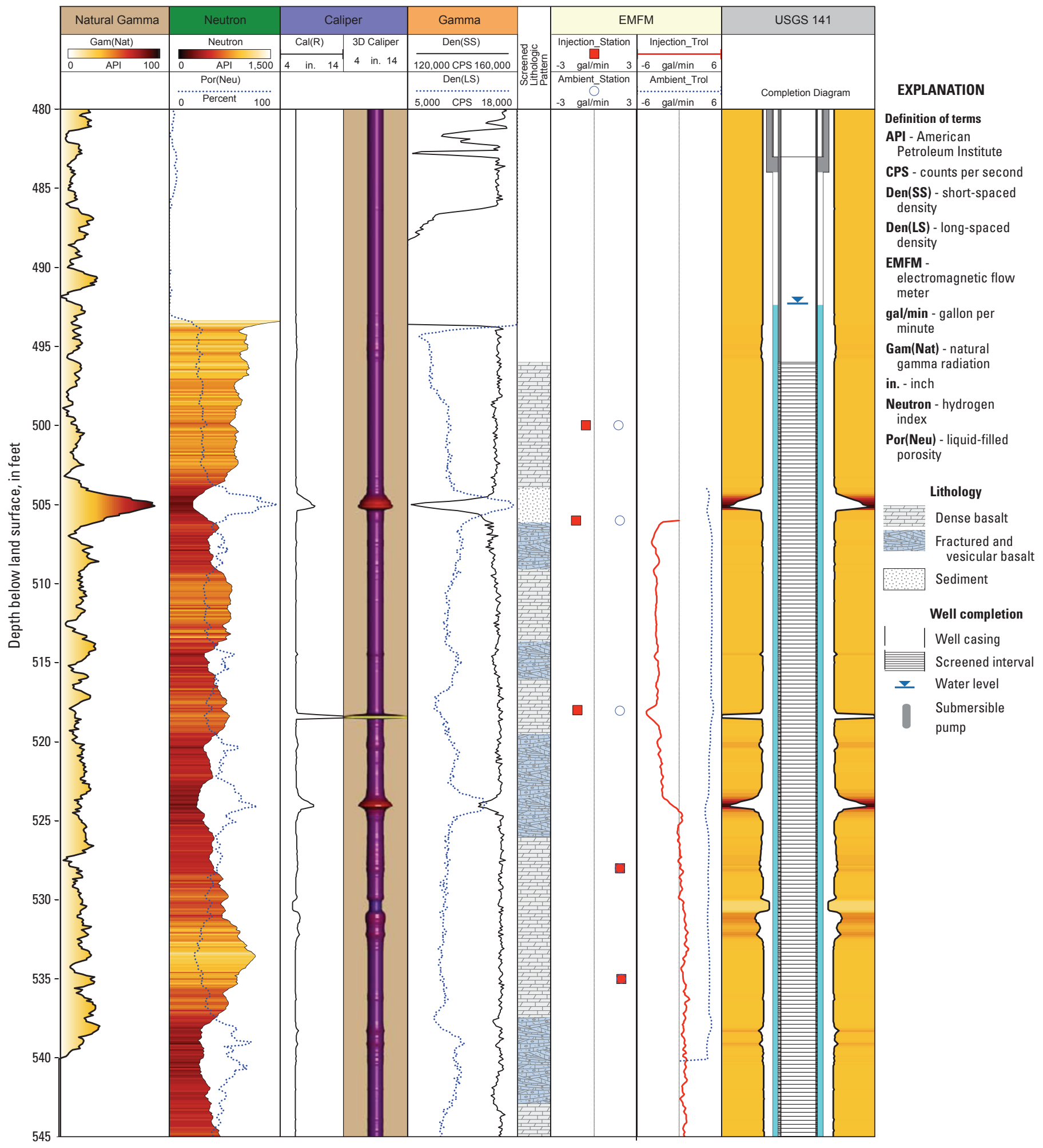

Figure 11. Expanded geophysical and lithologic logs with focus on depths $480-545$ feet below land surface for borehole USGS 141, Advanced Test Reactor Complex, Idaho National Laboratory, Idaho. 
Assuming basalt has a higher density than annular grout and sediment, density measurements can be used to examine annular seal behind 6-in. diameter casing and to correlate lithology. The primary disadvantage of using the omni-directional probe is that it does not provide a directionoriented (focused) measurement at the borehole wall and omni-directional density responds to spherical volume dominated by the immediate borehole; therefore, density measurements are ambiguous and bulk density cannot be accurately quantified (Yearsley and others, 1991).

Gamma-gamma dual density logs were collected during stages 1,2 , and 4 (fig. 9). Density logs were used to identify areas of dense, as opposed to fractured, basalt (figs. $7, \underline{8}, \underline{10}$, and 11). Additionally, attempts were made to determine the completeness of the annular grout seal behind 6-in. diameter casing by examining the difference between omni-directional density measurements taken before and after setting the grout seal in boreholes USGS 140 and USGS 141 between 0 and $480 \mathrm{ft} \mathrm{BLS}$ (fig. 12). Measurements collected during stage 1 were examined against measurements collected during stages 2 and 4 in boreholes USGS 140 and USGS 141, respectively; however, no attempts were made to correct for differences in borehole diameter or steel casing thickness.

Omni-directional density measurements in borehole USGS 140 (fig. 12) were subject to spherical volume differences owing to borehole size differences, where the drilled borehole size during stage 1 was $3.8 \mathrm{in}$. in diameter and the drilled borehole size during stage 2 was $8.0 \mathrm{in}$. in diameter. Between 0 and $480 \mathrm{ft}$ BLS, the annular grout seal appears to have several locations where minor voids appear; however, the annular grout seal appears mostly continuous from land surface to $480 \mathrm{ft}$ BLS. Measurements of omni-directional density in borehole USGS 141 were not subject to differences in spherical volume, where the 8-in. diameter drilled borehole size during stages 1 and 4 were equivalent. Borehole USGS 141 generally shows a mostly continuous grout seal between 0 and $480 \mathrm{ft}$ BLS; however, the omni-directional density appears to show a gap in annular seal between 190 and $240 \mathrm{ft}$ BLS. Drillers' notes explain that annular grout was pumped over 3 days, and after day 2 granular bentonite was used to help fill cavernous areas that were difficult to fill using grout. The 50-ft gap between 190 and $240 \mathrm{ft}$ BLS may have resulted when the granular bentonite seal formed a bridge near a sediment layer (fig. 12). Granular bentonite could be present between 190 and $240 \mathrm{ft}$ BLS, but that cannot be verified.

\section{Electromagnetic Flow Meter Logs}

The design of the EMFM is based on Faraday's Law of Induction: voltage induced by a conductor moving at right angles through a magnetic field is directly proportional to the velocity of the moving conductor. Groundwater flow through this magnetic field induces voltage that is measured by electrodes and the voltage then is used to calculate a volumetric flow rate. EMFM logs are used to identify vertical flow, to establish relative hydraulic gradients, and to identify transmissive fractures and zones. In fractured rock, it is important to conduct EMFM logging under both ambient and stressed conditions for both station and trolling measurements, where station measurements are collected between fractures that have been identified by caliper logs (Lane and others, 2002). Where depth to water exceeds several hundred feet, setting a pump to stress the aquifer was not practical; however, stressed station and trolling measurements were collected under continuous groundwater injection at about $19 \mathrm{gal} / \mathrm{min}$.

EMFM measurements were made during stage 4 (fig. 9) for boreholes USGS 140 and USGS 141 after the boreholes were allowed to stabilize for a few days following drilling and construction. Ambient and stressed station measurements were made at five depths between 500 and $540 \mathrm{ft}$ BLS. The EMFM was equipped with a 4.8 -in. diameter rubber diverter and centralizers to seal inside the 5-in. diameter well screen and direct groundwater flow through the EMFM throat; however, some groundwater bypass around the tool was expected where the rubber diverter cannot seal behind the 5-in. diameter well screen. Ambient and stressed trolling measurements were made starting at the bottom of the well and slowly trolling upward at a constant rate of $10 \mathrm{ft} / \mathrm{min}$. Attempts were made to hold a constant trolling speed during logging; trolling in the upward direction generally produced the best repeatability.

EMFM data collected for boreholes USGS 140 and USGS 141 show similar vertical groundwater rates (figs. 10 and 11). Ambient station measurements show upward flow rates ranging from 1.7 to $2.0 \mathrm{gal} / \mathrm{min}$ and minimal variation in both boreholes USGS 140 and USGS 141 (figs. 10 and 11). The stressed station measurements ("Injection_Station" in figures 10 and 11), taken during groundwater injection, show downward flow ranging from -1.5 to $-0.1 \mathrm{gal} / \mathrm{min}$ above $520 \mathrm{ft}$ BLS; however, between 520 and $545 \mathrm{ft}$ BLS, EMFM data indicate upward flow that ranged between 2.0 and $2.2 \mathrm{gal} / \mathrm{min}$ in boreholes USGS 140 and USGS 141 (figs. 10 and 11). Ambient and stressed trolling measurements ("Injection_Trol" in figures 10 and 11) were similar to station measurements. Ambient trolling measurements show consistent upward flow between 490 and $540 \mathrm{ft}$ BLS; stressed trolling measurements show a change in flow direction from downward to upward flow near 521 and $525 \mathrm{ft}$ BLS in boreholes USGS 140 and USGS 141, respectively (figs. 10 and 11). The change from downward flow to upward flow, under stressed conditions, suggests high transmissivity fractures between 520 and $525 \mathrm{ft}$ BLS in boreholes USGS 140 and USGS 141 (figs. 10 and 11). EMFM data suggest that groundwater pumped from boreholes USGS 140 and USGS 141 mostly originates from fractures below $520 \mathrm{ft}$ BLS. Basalt fractures near $500 \mathrm{ft}$ BLS in borehole USGS 140 and near $505 \mathrm{ft}$ BLS in borehole USGS 141 were described as having fine sediment that could result in a lowered capacity to produce groundwater under pumping conditions. Basalt fractures observed in borehole USGS 140 between 507 and $518 \mathrm{ft}$ BLS do not occur in borehole USGS 141, located about $375 \mathrm{ft}$ west; therefore, the productivity of borehole USGS 140 fractures between 507 and $518 \mathrm{ft}$ BLS could be limited if fractures are not laterally continuous. 


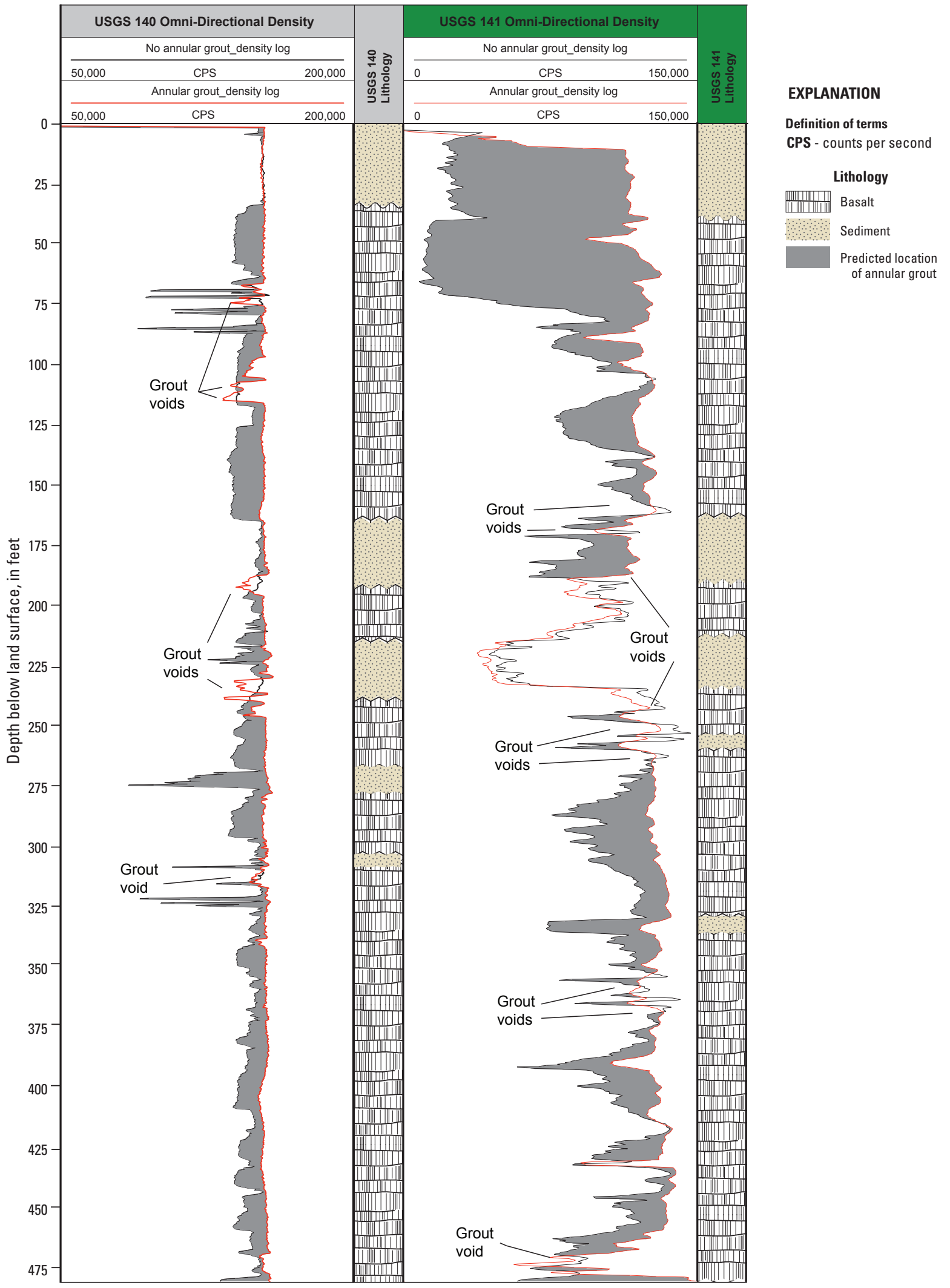

Figure 12. Geophysical gamma-gamma dual density logs used to examine annular grout seal 0-480 feet below land surface for boreholes USGS 140 and USGS 141, Advanced Test Reactor Complex, Idaho National Laboratory, Idaho. 


\section{Gyroscopic Deviation Survey}

Borehole gyroscopic deviation surveys were run during stage 4 (fig. 9) for boreholes USGS 140 and USGS 141 (fig. 13). The gyroscopic deviation survey measures the vertical deviation of a borehole from land surface to the bottom of the hole. Deviation was measured every $0.1 \mathrm{ft}$ and shown in 50-ft increments from 0 to $540 \mathrm{ft}$ BLS. Borehole USGS 140 indicates a 15.7-ft horizontal deviation at a projected 110.3-degree azimuth near $490 \mathrm{ft}$ BLS. Borehole USGS 141 indicates a 2.4-ft horizontal deviation at a projected 55.9-degree azimuth near $490 \mathrm{ft}$ BLS. The calculated offsets for boreholes USGS 140 and USGS 141 account for horizontal and vertical displacements at various depths; however, at a depth near $490 \mathrm{ft}$ BLS (approximate water table), the calculated offsets (cable depths-true drill hole depths) were 0.26 and $0.02 \mathrm{ft}$ for boreholes USGS 140 and USGS 141, respectively. The USGS uses a water-level correction when the gyroscopic deviation survey suggests the calculated offset exceeds $0.10 \mathrm{ft}$; therefore, to account for deviation near the water table in borehole USGS 140, a deviation correction of $0.26 \mathrm{ft}$ was subtracted from water-level measurements. No water-level correction was necessary for borehole USGS 141, where the calculated offset was less than $0.1 \mathrm{ft}$. A summary of borehole-deviation measurements is presented in table 3 .

Table 3. Summary of gyroscopic deviation data from processed survey for boreholes USGS 140 and USGS 141, Advanced Test Reactor Complex, Idaho National Laboratory, Idaho.

[Borehole deviation profile shown in figure 13. Survey performed using a Century Geophysical Corporation ${ }^{\mathrm{TM}}$ 9095 logging tool. A tripod was used to hold the tool vertical during warmup. During warmup, the following information was noted: reference sighting azimuth, land surface drilling datum height, and magnetic declination (12.46 degrees). Abbreviations: BLS, below land surface; ft, foot; TDD-CD, true drill hole depthcable depth]

\begin{tabular}{|c|c|c|c|c|c|}
\hline Local name & $\begin{array}{l}\text { Cable depth } \\
\text { (ft BLS) }\end{array}$ & $\begin{array}{l}\text { Horizontal deviation } \\
\text { from vertical } \\
\text { (ft) }\end{array}$ & $\begin{array}{l}\text { True drill hole } \\
\text { depth } \\
\text { (ft) }\end{array}$ & $\begin{array}{c}\text { Calculated offset } \\
\text { (TDD-CD) } \\
\text { (ft) }\end{array}$ & $\begin{array}{c}\text { Drill hole } \\
\text { azimuth } \\
\text { (degrees) }\end{array}$ \\
\hline \multirow[t]{11}{*}{ USGS 140} & 50 & 1.2 & 49.98 & -0.02 & 112.7 \\
\hline & 100 & 2.8 & 99.96 & -0.04 & 108.2 \\
\hline & 150 & 4.8 & 149.92 & -0.08 & 123.4 \\
\hline & 200 & 6.6 & 199.88 & -0.12 & 113.0 \\
\hline & 250 & 8.3 & 249.85 & -0.15 & 114.2 \\
\hline & 300 & 10.0 & 299.82 & -0.18 & 122.5 \\
\hline & 350 & 11.6 & 349.79 & -0.21 & 116.3 \\
\hline & 400 & 13.2 & 399.77 & -0.23 & 113.1 \\
\hline & 450 & 14.4 & 449.81 & -0.19 & 115.9 \\
\hline & ${ }^{1} 490$ & 15.7 & 489.74 & -0.26 & 110.3 \\
\hline & 500 & 15.7 & 499.73 & -0.27 & 110.1 \\
\hline \multirow[t]{11}{*}{ USGS 141} & 50 & 0.2 & 50.00 & 0.00 & 141.9 \\
\hline & 100 & 0.4 & 100.00 & 0.00 & 101.0 \\
\hline & 150 & 0.7 & 150.00 & 0.00 & 92.0 \\
\hline & 200 & 1.1 & 199.99 & -0.01 & 77.2 \\
\hline & 250 & 1.5 & 249.99 & -0.01 & 74.9 \\
\hline & 300 & 1.9 & 299.99 & -0.01 & 64.1 \\
\hline & 350 & 2.2 & 349.99 & -0.01 & 61.2 \\
\hline & 400 & 2.5 & 399.99 & -0.01 & 57.7 \\
\hline & 450 & 2.5 & 449.98 & -0.02 & 55.0 \\
\hline & ${ }^{1} 490$ & 2.4 & 489.98 & -0.02 & 55.9 \\
\hline & 500 & 2.4 & 499.98 & -0.02 & 55.4 \\
\hline
\end{tabular}

\footnotetext{
${ }^{1}$ Represents measurement taken near the water table.
} 


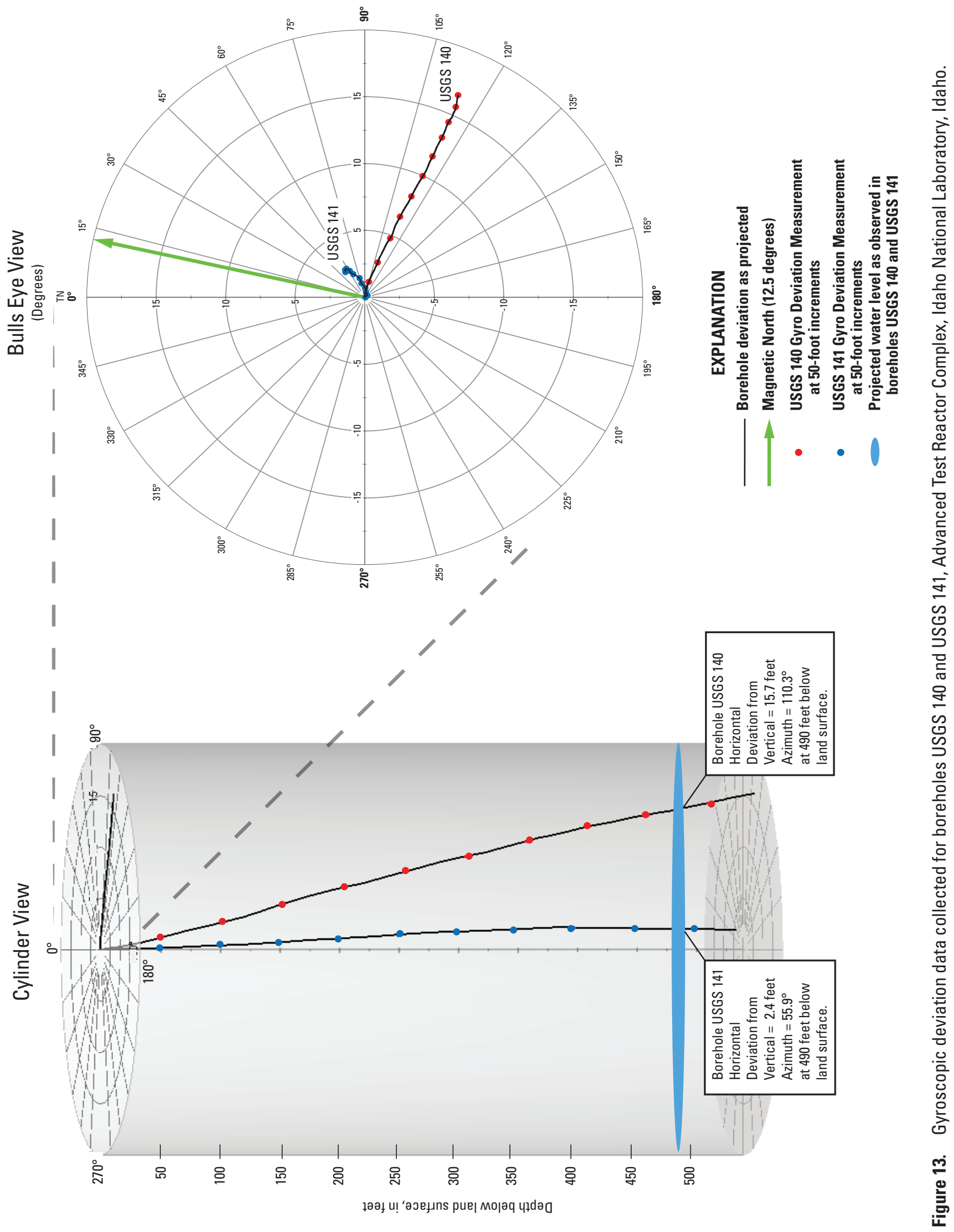




\section{Aquifer Tests}

Single-well aquifer tests were conducted for wells USGS 140 and USGS 141, both constructed about $50 \mathrm{ft}$ into the ESRP aquifer. Two aquifer tests were recorded for well USGS 140. The first aquifer test lasted about 22 hours and indicated no measurable drawdown, and the second aquifer test lasted about 1 hour. The first aquifer test at well USGS 140 started at 10:00 a.m. on July 30,2013 , and ended at 08:30 a.m. on July 31,2013 , whereas the second aquifer test started at 09:11 a.m. on July 31, 2013, and ended at 10:10 a.m. on July 31, 2013. The second aquifer test was done at well USGS 140 because no measurable drawdown was observed during the first aquifer test so data were collected for the second test where barometric change was minimal. A single aquifer test was recorded for well USGS 141 starting at 09:00 a.m. on September 24, 2013, and ending at 09:52 a.m. on September 25, 2013, lasting about 25 hours. Aquifer testing was done immediately following construction and results from these tests were used to determine monitor well production capacity and average hydraulic properties of rocks near the well. The hydraulic-property estimates were recorded in the USGS Groundwater Site Inventory database, and data collected during the aquifer test were archived in the USGS Idaho Water Science Center Aquifer Test Archive.

The aquifer-test data were analyzed for pressure change in response to groundwater pumping and atmospheric conditions. Barometric efficiency was not used to correct water-level data because atmospheric loading in these aquifer systems is complex and would require the collection of time-series data over several weeks, which was not done as part of this investigation. Prolonged aquifer tests confirmed that wells USGS 140 and USGS 141 met or exceeded sustained discharge rates of $24 \mathrm{gal} / \mathrm{min}$ with minimal drawdown. Water samples were collected after purging the wells for about 24 hours.

\section{Aquifer-Test Procedures}

During the single-well aquifer testing in wells USGS 140 and USGS 141, fluid pressure head, barometric head, and air temperature were measured continuously. The fluid pressure head, $\Psi_{w}$, was measured with a Solinst ${ }^{\circledR}$ Levelogger ${ }^{\circledR}$, a self-contained datalogger suspended on a wireline and positioned about $10 \mathrm{ft}$ below the water table (fig. 14). The barometric head pressure, $\Psi_{a t m}$, and air temperature were measured with a Solinst ${ }^{\circledR}$ Barologger ${ }^{\circledR}$, a self-contained atmospheric pressure and temperature datalogger suspended on a wireline and positioned above the water table (figs. 14 and 15). The fluid pressure head was compensated for changes in atmospheric pressure for USGS 140 and USGS 141 during the aquifer test and calculated using the following equation:

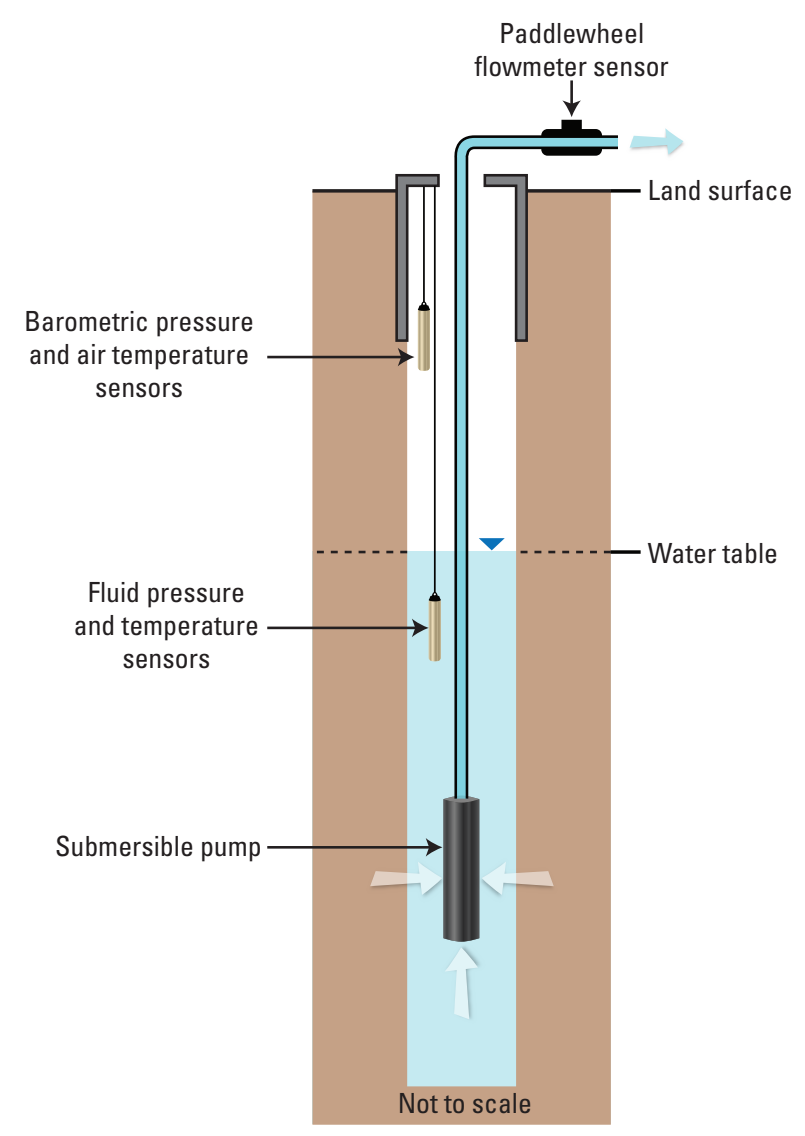

Figure 14. Idealized placement of sensors during aquifer testing at wells USGS 140 and USGS 141, Advanced Test Reactor Complex, Idaho National Laboratory, Idaho.

$$
\Psi=\Psi_{w}-\Psi_{a t m}
$$

where

$\Psi$ is compensated pressure head,

$\Psi_{w}$ is fluid pressure head, and

$\Psi_{\text {atm }}$ is barometric head pressure.

After the pump was turned off, aquifer-test recovery data were collected, but were not analyzed.

The flow rate, in gallons per minute, was monitored periodically using a Blue-White Industries ${ }^{\circledR}$ F-2000 paddlewheel flowmeter (fig. 14). Measured flow rates remained relatively constant at well USGS 140 with an average of 23.9 and $23.7 \mathrm{gal} / \mathrm{min}$ during the first and second aquifer tests, respectively, and at well USGS 141 with an average of $23.4 \mathrm{gal} / \mathrm{min}$ (appendix C). 

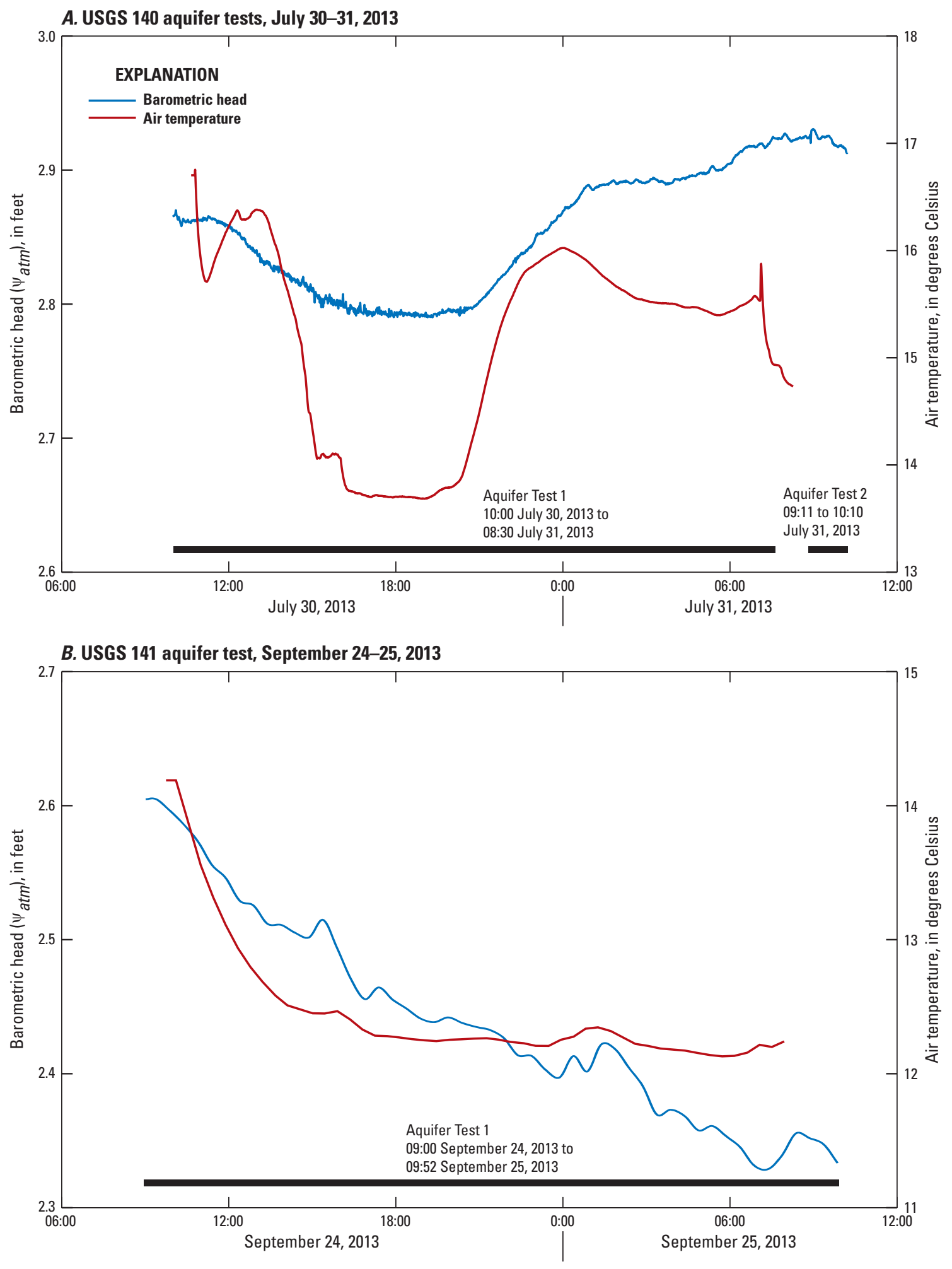

Figure 15. Changes in barometric head and air temperature through time at $(A)$ well USGS 140, and $(B)$ well USGS 141, Advanced Test Reactor Complex, Idaho National Laboratory, Idaho. 


\section{Analysis of Aquifer-Test Data}

The single-well aquifer tests for wells USGS 140 and USGS 141 were analyzed using a specific-capacity method to estimate transmissivity (Ackerman, 1991). This method uses linear regression to estimate transmissivity (feet squared per day) near the well from specific capacity (gallons per minute per foot) (fig. 16). The specific-capacity method uses a modified Theis equation (Theis and others, 1963, p. 332, equation 1) and assumes constant values for the storage coefficient and the effective well radius to estimate transmissivity. Because of the limited drawdown response $(<0.1 \mathrm{ft})$ and no observation well data, the specific-capacity method was the only method considered for estimating hydraulic properties for wells USGS 140 and USGS 141.

Specific capacity $(S C)$ is an expression of the productivity of a well and is commonly expressed as the ratio of the pumping rate $(Q)$ in gallons per minute to the total measured drawdown $(\Delta s)$ in feet; see equation 2 . Drawdown data for well USGS 140 was approximated for aquifer test 2 at $0.01 \mathrm{ft}$ (fig. 17A) between 5 and 25 minutes; no measureable drawdown was reported during aquifer test 1 . The production capacity of well USGS 140 likely exceeds the pumping capacity of $24 \mathrm{gal} / \mathrm{min}$ and a larger capacity pump would be required to produce additional aquifer drawdown at this location. Drawdown data for well USGS 141 was approximated at $0.05 \mathrm{ft}$ between 5 and 100 minutes (fig. 17B $)$. Solinst ${ }^{\circledR}$ Levelogger ${ }^{\circledR}$ fluid pressure measurements collected for wells USGS 140 and USGS 141 agree with electric tape measurements taken during the aquifer tests (appendix C). A time-series analysis of water-level change in response to barometric pressure could be examined to approximate barometric efficiency and to help remove the effects of atmospheric loading near these wells where barometric effects on water level data during aquifer testing is significant. Recording subtle pressure change in response to aquifer pumping is difficult in fractured media with very high transmissivity, such as was observed in wells USGS 140 and USGS 141.

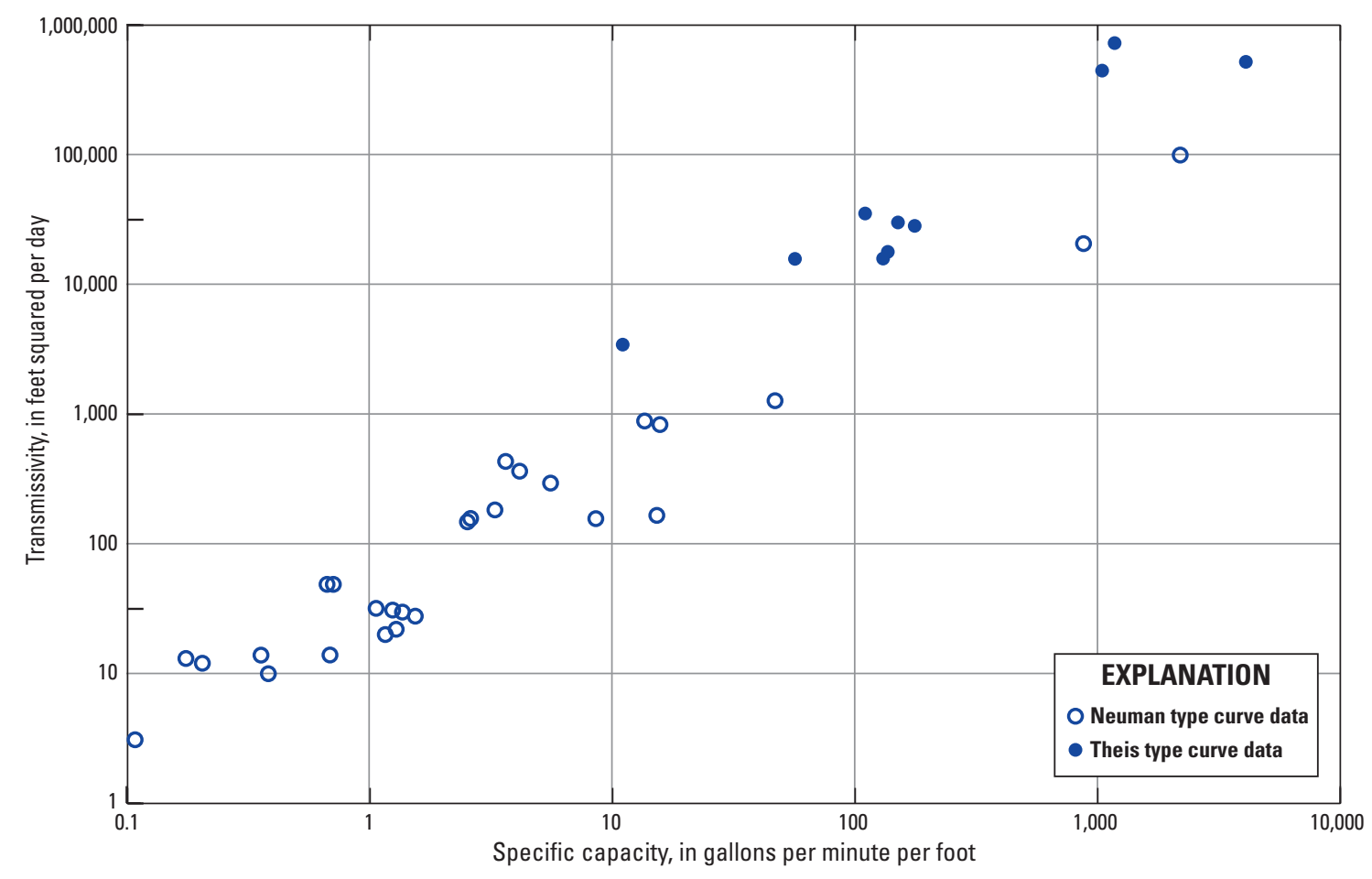

Figure 16. Relation between transmissivity and specific capacity derived from aquifer testing for wells completed within the eastern Snake River Plain aquifer, Idaho (modified from Ackerman, 1991). 


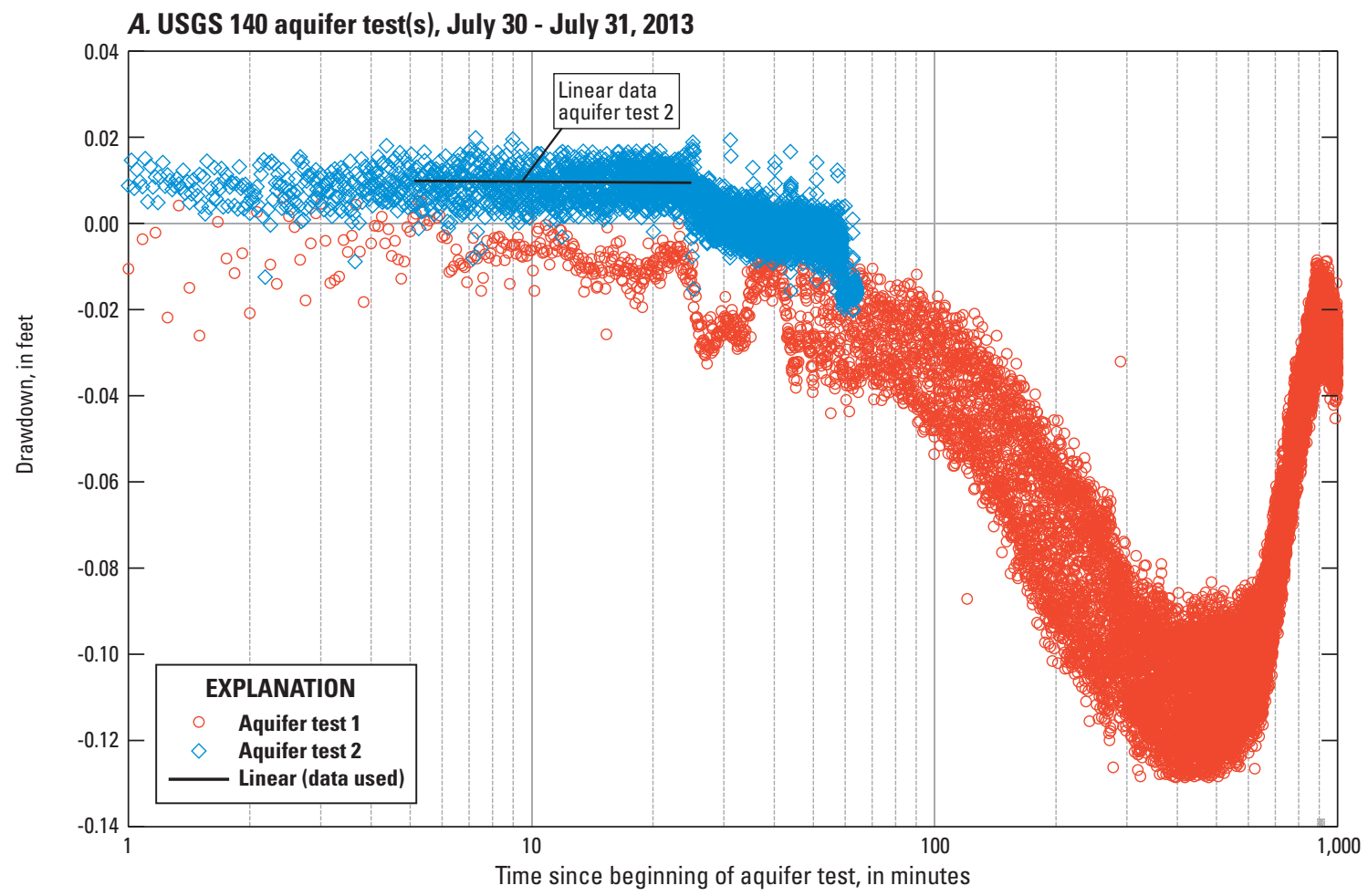

B. USGS 141 aquifer test, September 24-25, 2013

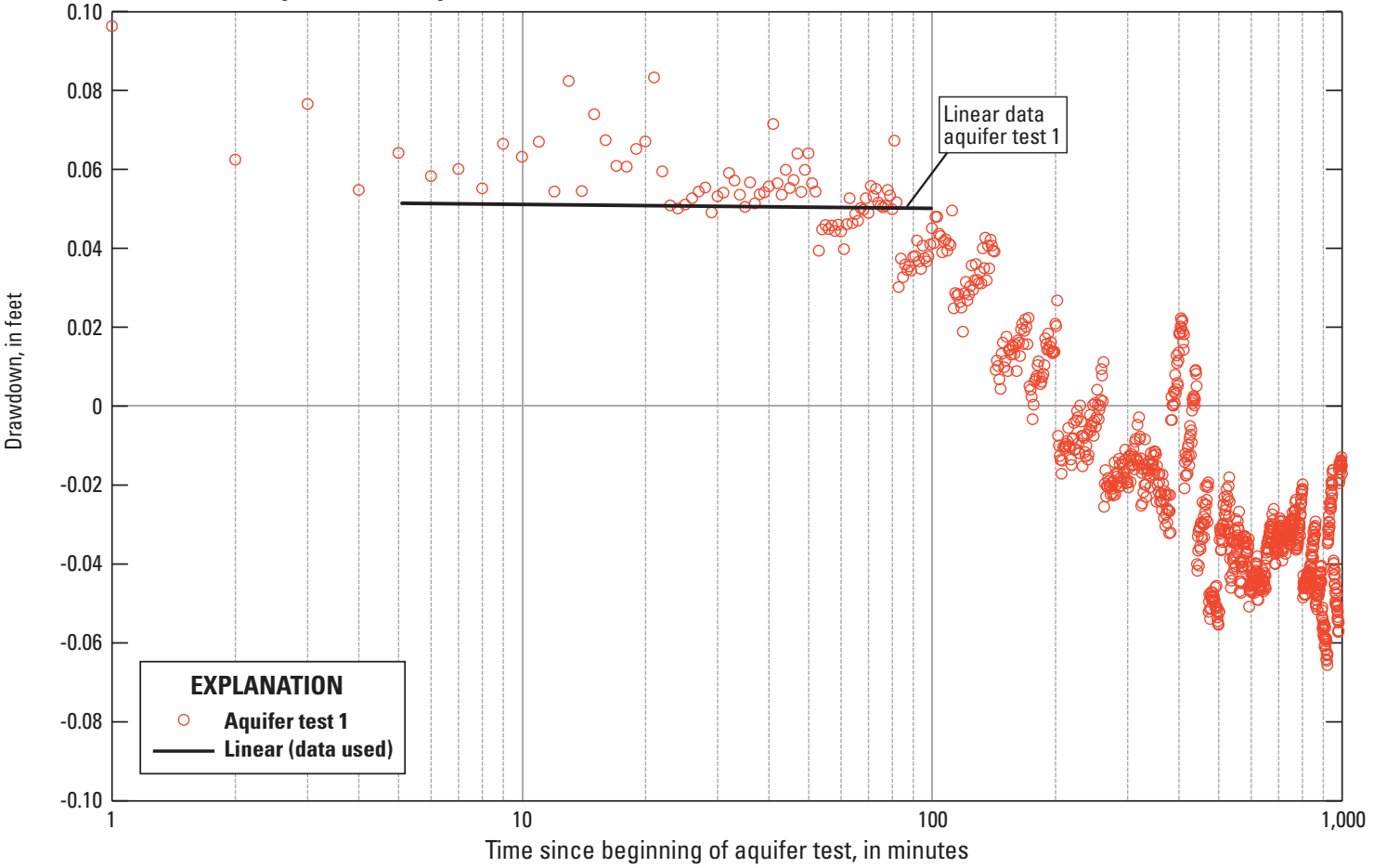

Figure 17. Analyses of drawdown time series for aquifer tests at (A) well USGS 140 (July 30-31, 2013), and (B) well USGS 141 (September 24-25, 2013), Advanced Test Reactor Complex, Idaho National Laboratory, Idaho. 
The specific-capacity method estimates transmissivity $(T)$ through the use of the following equations:

$$
\begin{gathered}
S C=\left(\frac{Q}{\Delta s}\right) \\
T=(S C)^{1.1853} \times 40.62=\left(\frac{Q}{\Delta s}\right)^{1.1853} \times 40.62
\end{gathered}
$$

where

$T$ is the transmissivity, in feet squared per day;

$S C$ is the specific capacity, in gallons per minute per foot;

$Q$ is the pumping rate, in gallons per minute; and

$\Delta s$ is the average drawdown, in feet.

The drawdown in the well, $\Delta s$, at any given time, $t$, is determined by subtracting the compensated pressure head at time $t$ from the initial compensated pressure head prior to pumping, $\Psi_{0}$. Drawdown as a function of time is expressed as:

$$
s(t)=\Psi_{0}-\Psi(\mathrm{t})
$$

Estimates of horizontal hydraulic conductivity were based on the aquifer thickness, $b$, rather than the screen length because Halford and others (2006) determined that in most cases using aquifer thickness as the divisor gave better estimates of transmissivity for unconfined aquifers with partial penetration. The horizontal hydraulic conductivity, $K$, was calculated using the following equation:

$$
K=\frac{T}{b}
$$

where

$T$ is aquifer transmissivity, and

$b$ is aquifer thickness.

\section{Hydraulic Property Estimates}

The two hydraulic properties defined for the hydrogeologic column in wells USGS 140 and USGS 141 were transmissivity and horizontal hydraulic conductivity (conductivity). Transmissivity was estimated by an interpretive approach; not all data were honored and only relevant data were used. The specific-capacity method applied to the aquifer tests is shown in figures 16 and 17 . The specific capacity, transmissivity, and conductivity for well USGS 140 were estimated at 2,370 ( gal $/ \mathrm{min}) / \mathrm{ft}, 4.06 \times 10^{5} \mathrm{ft}^{2} / \mathrm{d}$, and $740 \mathrm{ft} / \mathrm{d}$, respectively. Calculations of these three parameters are as follows:

$$
\begin{gathered}
S C=\left(\frac{Q}{\Delta s}\right)=\frac{23.7 \mathrm{gal} / \mathrm{min}}{0.01 \mathrm{ft}}=2,370(\mathrm{gal} / \mathrm{min}) / \mathrm{ft} \\
T=(S C)^{1.1853} \times 40.62=(2,370(\mathrm{gal} / \mathrm{min}) / \mathrm{ft})^{1.1853} \\
\\
\times 40.62=4.06 \times 10^{5} \mathrm{ft}^{2} / \mathrm{d} \\
K=\frac{T}{b}=\frac{4.06 \times 10^{5} \mathrm{ft}^{2} / \mathrm{d}}{550 \mathrm{ft}}=740 \mathrm{ft} / \mathrm{d}
\end{gathered}
$$

The specific capacity, transmissivity, and conductivity for well USGS 141 were estimated at $470(\mathrm{gal} / \mathrm{min}) / \mathrm{ft}$, $5.95 \times 10^{4} \mathrm{ft}^{2} / \mathrm{d}$, and $110 \mathrm{ft} / \mathrm{d}$, respectively. Calculations of these three parameters are as follows:

$$
\begin{gathered}
S C=\left(\frac{Q}{\Delta s}\right)=\frac{23.4 \mathrm{gal} / \mathrm{min}}{0.05 \mathrm{ft}}=470(\mathrm{gal} / \mathrm{min}) / \mathrm{ft} \\
T=(S C)^{1.1853} \times 40.62=(470(\mathrm{gal} / \mathrm{min}) / \mathrm{ft})^{1.1853} \\
\\
\times 40.62=5.95 \times 10^{4} \mathrm{ft}^{2} / \mathrm{d} \\
K=\frac{T}{b}=\frac{5.95 \times 10^{4} \mathrm{ft}^{2} / \mathrm{d}}{550 \mathrm{ft}}=110 \mathrm{ft} / \mathrm{d}
\end{gathered}
$$

A comparison between the estimated transmissivity for wells USGS 140 and USGS 141 and the transmissivity values determined from past aquifer tests conducted at wells near the ATR Complex shows reasonable agreement (fig. 2 , table 4). The estimated transmissivity values from these past aquifer tests (Ackerman, 1991; Bartholomay and others, 1997; Twining and others, 2012) ranged from $9.5 \times 10^{3}$ to $1.9 \times 10^{5} \mathrm{ft}^{2} / \mathrm{d}$ (table 4). The average hydraulic conductivity estimated for wells USGS 140 and USGS 141 was within the range of values reported in the literature for similar rock types. Freeze and Cherry (1979) reported hydraulic conductivity values for permeable basalt ranging from $5.7 \times 10^{-2}$ to $5.7 \times 10^{3} \mathrm{ft} / \mathrm{d}$. The hydraulic conductivity of the ESRP aquifer at or near the INL ranges from about $1.0 \times 10^{-2}$ to $3.2 \times 10^{4} \mathrm{ft} / \mathrm{d}$ (Anderson and others, 1999). 
Table 4. Comparison of transmissivity values estimated from aquifer tests at wells near wells USGS 140 and USGS 141, near the Advanced Test Reactor Complex, Idaho National Laboratory, Idaho.

[Data from Ackerman (1991), Bartholomay and others (1997), and Twining and others (2012). Locations of wells are shown in figure 2. Local name: Local well identifier used in this study. TRA, Test Reactor Area. Site identifier: Unique numerical identifier used to access well data (http://waterdata.usgs.gov/nwis); Longitude and Latitude: Referenced to NAD 27 (North American Datum of 1927). Distance to wells: Straight line distance within the aerial dimension to wells USGS 140 and USGS 141. Abbreviations: $\mathrm{ft}^{2} / \mathrm{d}$, foot squared per day; mi, mile]

\begin{tabular}{lccccc}
\hline \multicolumn{1}{c}{ Local name } & Site identifier & Longitude & Latitude & $\begin{array}{c}\text { Transmissivity } \\
\text { (ft' } \mathbf{d} \text { ) }\end{array}$ & $\begin{array}{c}\text { Distance to } \\
\text { wells } \\
\text { (mi) }\end{array}$ \\
\hline USGS 136 & 433447112581501 & $112^{\circ} 58^{\prime} 12^{\prime \prime}$ & $43^{\circ} 34^{\prime} 48^{\prime \prime}$ & $1.4 \times 10^{5}$ & 0.1 \\
USGS 76 & 433425112573201 & $112^{\circ} 57^{\prime} 32^{\prime \prime}$ & $43^{\circ} 34^{\prime} 25^{\prime \prime}$ & $1.9 \times 10^{5}$ & 0.7 \\
USGS 58 & 433500112572502 & $112^{\circ} 57^{\prime} 25^{\prime \prime}$ & $43^{\circ} 35^{\prime} 00^{\prime \prime}$ & $3.7 \times 10^{4}$ & 0.6 \\
USGS 65 & 433447112574501 & $112^{\circ} 57^{\prime} 47^{\prime \prime}$ & $43^{\circ} 34^{\prime} 46^{\prime \prime}$ & $9.5 \times 10^{3}$ & 0.5 \\
Site 19 & 433522112582101 & $112^{\circ} 58^{\prime} 21^{\prime \prime}$ & $43^{\circ} 35^{\prime} 22^{\prime \prime}$ & $3.1 \times 10^{4}$ & 0.7 \\
TRA disposal & 433506112572301 & $112^{\circ} 57^{\prime} 36^{\prime \prime}$ & $43^{\circ} 35^{\prime} 06^{\prime \prime}$ & $6.2 \times 10^{4}$ & 0.5 \\
\hline
\end{tabular}

\section{Water-Sample Collection}

\section{Sample Collection Methods}

Water-sample collection at wells USGS 140 and USGS 141 generally followed guidelines documented in the USGS National Field Manual for the Collection of Water-Quality Data (U.S. Geological Survey, variously dated) and in Knobel and others (2008); water-quality samples were collected toward the end of aquifer testing in wells USGS 140 and USGS 141, after the wells were allowed to purge for about 24 hours. Water-quality samples were collected from USGS 140 and USGS 141 on July 31 and September 25, 2013 , respectively. Water samples were collected from a 0.25 -in. diameter SS sample port installed off wellhead piping after the well was purged with a submersible pump and field measurements were stable. The constituents sampled after well completion were selected to provide a characterization of baseline water chemistry and radionuclide concentrations. Field measurements of water temperature, $\mathrm{pH}$, specific conductance, dissolved oxygen, and alkalinity were collected during both sample rounds; results are presented in table 5 .

Samples were processed in the field according to protocols for the constituents for which analyses were requested. Samples to be analyzed for chemical constituents by the USGS National Water Quality Laboratory (NWQL) were placed in containers and preserved in accordance with laboratory requirements specified by Knobel and others (2008, appendix D). Containers and preservatives used were supplied by the NWQL and had gone through a rigorous quality-control procedure (Pritt, 1989, p. 75) to minimize sample contamination. Samples requiring field filtration were filtered through a disposable $0.45-\mu \mathrm{m}$ cartridge that had been pre-rinsed with at least $1 \mathrm{~L}$ of deionized water. Samples to be analyzed for radionuclides by the Radiological and Environmental Sciences Laboratory (RESL) at the INL were placed in containers and preserved in accordance with laboratory requirements specified by Bodnar and Percival (1982) and Knobel and others (2008, appendix D). Samples for isotopes of oxygen and hydrogen were collected in bottles provided by the USGS Reston Stable Isotope Laboratory-Isotope Fractionation Project in Reston, Virginia, and analyzed by that laboratory. Samples for carbon-13 were collected in bottles provided by the NWQL, and these samples were analyzed at the National Ocean Sciences Accelerator Mass Spectrometry Facility in Woods Hole, Massachusetts. Samples for radioactivity emitted as carbon-14 were collected in bottles provided by the NWQL and analyzed for INL site contractor Battelle Energy Alliance (BEA) by GEL Laboratories LLC in Charleston, South Carolina. The carbon-14 data are presented here for completeness of available data.

\section{Analytical Methods}

Analytical methods used by the USGS for selected organic, inorganic, and radionuclide constituents are described by Goerlitz and Brown (1972), Thatcher and others (1977), Wershaw and others (1987), Fishman and Friedman (1989), Faires (1993), Fishman (1993), Rose and Schroeder (1995), and McCurdy and others (2008). Analytical methods used for selected isotopic constituents were summarized by Busenberg and others (2000). A discussion of procedures and methods used by the RESL for the analysis of radionuclides in water is provided by Bodnar and Percival (1982), Sill and Sill (1994), and the U.S. Department of Energy (1995). 
Table 5. Concentrations of selected chemical and radiochemical constituents in water from wells USGS 140 and USGS 141 , near the Advanced Test Reactor Complex, Idaho National Laboratory, Idaho.

[Locations of wells are shown in figure 1. Analytical results in micrograms per liter (mg/L) unless noted otherwise. Samples collected on 07-31-13 and 09-25-13 were from a 5-horsepower submersible pump at 526 feet below land surface. Samples were analyzed at the USGS National Water Quality Laboratory in Lakewood, Colo. unless indicated otherwise. Uncertainty of radiochemical constituents is $1 s$. Uncertainity of deuterium and oxygen-18 is \pm 1.5 per mil. Uncertainty of carbon-13 is \pm 0.3 per mil. Radiochemical concentrations that meet or exceed the reporting level of 3 times the $1 s$ value are shown in boldface type. Abbreviations: NOSAMS, National Ocean Sciences Accelerator Mass Spectrometry Laboratory in Woods Hole, Mass.; RESL, Radiological and Environmental Sciences Laboratory; RSIL, USGS Reston Stable Isotope Laboratory in Reston, Va.; NTU, nephelometric turbidity units; ${ }^{\circ} \mathrm{C}$, degrees Celsius; $\mu \mathrm{S} / \mathrm{cm}$, microsiemens per centimeter at 25 degrees Celsius; $\mathrm{CaCO}_{3}$, calcium carbonate; $\mathrm{pCi} / \mathrm{L}$, picocuries per liter; N, nitrogen; $\mathrm{P}$, phosphorus; E, estimated; NA, not analyzed; $s$, sample standard deviation. $<$, less than; \pm , plus or minus]

\begin{tabular}{|c|c|c|c|c|c|}
\hline Constituent or measurement & USGS 140 & USGS 141 & Constituent or measurement & USGS 140 & USGS 141 \\
\hline Time & 09:35 & 09:00 & Copper & $<0.80$ & $<0.80$ \\
\hline Air temperature $\left({ }^{\circ} \mathrm{C}\right)$ & 21.7 & 7.3 & Lead & $<0.025$ & $<0.025$ \\
\hline pH (field) & 7.8 & 7.8 & Lithium & 2.41 & 2.28 \\
\hline $\mathrm{pH}$ (laboratory) & 8.1 & 8.0 & Manganese & E0.192 & 0.37 \\
\hline \multirow{2}{*}{$\begin{array}{l}\text { Specific conductance }(\mu \mathrm{S} / \mathrm{cm}) \\
\quad \text { (laboratory) }\end{array}$} & \multirow[t]{2}{*}{428} & \multirow[t]{2}{*}{428} & Nickel & 0.335 & 0.580 \\
\hline & & & Selenium & 1.14 & 1.10 \\
\hline Dissolved oxygen $(\mathrm{mg} / \mathrm{L})$ & 8.2 & 9.2 & Silver & $<0.005$ & $<0.005$ \\
\hline Alkalinity $\left(\mathrm{mg} / \mathrm{L}\right.$ as $\left.\mathrm{CaCO}_{3}\right)$ & 166 & 167 & Strontium & 231 & 222 \\
\hline Turbidity (NTU) & 1.27 & 0.65 & Thallium & $<0.010$ & $<0.010$ \\
\hline Silica & 20.8 & 21.1 & Tritium (pCi/L) (RESL) & $2,010 \pm 80$ & $1,920 \pm 80$ \\
\hline Sodium & 12.6 & 11.4 & Strontium-90 (pCi/L) (RESL) & $0.3 \pm 0.7$ & $0.9 \pm 0.7$ \\
\hline Bromide & 0.039 & 0.039 & Technetium-99 (pCi/L) (RESL) & $0.01 \pm 0.04$ & $0.08 \pm 0.04$ \\
\hline Chloride & 12.6 & 12.1 & Iodine-129 (pCi/L) (RESL) & $-0.2 \pm 0.2$ & $0.01 \pm 0.12$ \\
\hline Fluoride & 0.17 & 0.15 & Carbon-14 (pCi/L) (GEL) & $5.71 \pm 1.47$ & $8.04 \pm 1.74$ \\
\hline Sulfate & 41.0 & 38.6 & Cesium-137 (pCi/L) (RESL) & $21 \pm 9$ & $2 \pm 4$ \\
\hline Ammonia as $\mathrm{N}$ & $<0.010$ & $<0.010$ & Gross alpha (pCi/L) (RESL) & $1.7 \pm 1.6$ & $2 \pm 2$ \\
\hline Nitrite as $\mathrm{N}$ & $<0.001$ & $<0.001$ & Gross beta (pCi/L) (RESL) & $2.1 \pm 0.8$ & $1.1 \pm 0.7$ \\
\hline Nitrate plus nitrite as $\mathrm{N}$ & 1.09 & 1.07 & Americium-241 (pCi/L) (RESL) & $0.003 \pm 0.011$ & $0.012 \pm 0.012$ \\
\hline Orthophosphate as $\mathrm{P}$ & 0.021 & 0.069 & Plutonium-238 (pCi/L) (RESL) & $-0.003 \pm 0.003$ & $-0.003 \pm 0.003$ \\
\hline Aluminum & 5.34 & 6.00 & Plutonium-239,240 (pCi/L) & $0.009 \pm 0.008$ & $0.003 \pm 0.005$ \\
\hline
\end{tabular}


Table 5. Concentrations of selected chemical and radiochemical constituents in water from wells USGS 140 and USGS 141, near the Advanced Test Reactor Complex, Idaho National Laboratory, Idaho—Continued.

[Locations of wells are shown in figure 1. Analytical results in micrograms per liter $(\mathrm{mg} / \mathrm{L})$ unless noted otherwise. Samples collected on 07-31-13 and 09-25-13 were from a 5-horsepower submersible pump at 526 feet below land surface. Samples were analyzed at the USGS National Water Quality Laboratory in Lakewood, Colo. unless indicated otherwise. Uncertainty of radiochemical constituents is $1 s$. Uncertainity of deuterium and oxygen-18 is \pm 1.5 per mil. Uncertainty of carbon- 13 is \pm 0.3 per mil. Radiochemical concentrations that meet or exceed the reporting level of 3 times the $1 s$ value are shown in boldface type. Abbreviations: NOSAMS, National Ocean Sciences Accelerator Mass Spectrometry Laboratory in Woods Hole, Mass.; RESL, Radiological and Environmental Sciences Laboratory; RSIL, USGS Reston Stable Isotope Laboratory in Reston, Va.; NTU, nephelometric turbidity units; ${ }^{\circ} \mathrm{C}$, degrees Celsius; $\mu \mathrm{S} / \mathrm{cm}$, microsiemens per centimeter at 25 degrees Celsius; $\mathrm{CaCO}_{3}$, calcium carbonate; $\mathrm{pCi} / \mathrm{L}$, picocuries per liter; $\mathrm{N}$, nitrogen; $\mathrm{P}$, phosphorus; E, estimated; NA, not analyzed; $s$, sample standard deviation. $<$, less than; \pm , plus or minus]

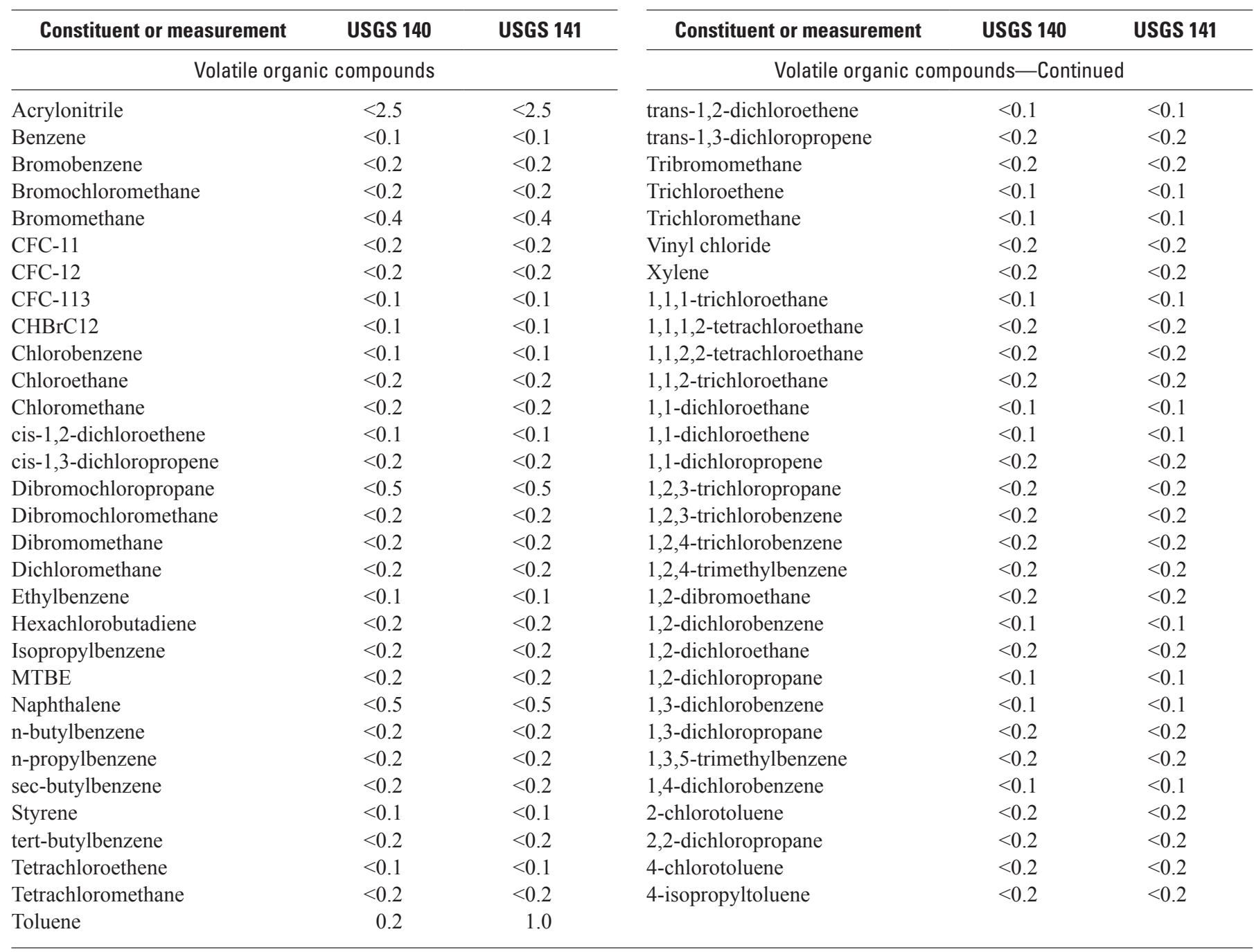




\section{Guidelines for Interpretation of Analytical Results}

Concentrations of radionuclides are reported with an estimated sample standard deviation, $\boldsymbol{s}$, which is obtained by propagating sources of analytical uncertainty in measurements. McCurdy and others (2008) provided details on interpreting radiological data used by the USGS. The guidelines for interpreting analytical results are based on an extension of a method proposed by Currie (1984) that is given in Davis and others (2013). In this report, radionuclide concentrations less than $3 \boldsymbol{s}$ are considered to be less than the "reporting level." The reporting level should not be confused with the analytical method detection limit, which is based on laboratory procedures.

Concentrations of inorganic and organic constituents are reported with reference to long-term method detection levels (LT-MDLs), laboratory reporting levels (LRLs), interim reporting levels (IRLs), or to minimum reporting levels (MRLs). Childress and others (1999) provide details about the approach used by the USGS regarding detection levels and reporting levels. USGS Office of Water Quality Technical Memorandum 2010.07 (U.S. Geological Survey, 2010) outlines changes to data reporting by the NWQL for the inorganic and organic constituents. The primary change was that the reporting level for most inorganic constituents was set at the LT-MDL. The method detection limit is the minimum concentration of a substance that can be measured and reported with 99-percent confidence that the concentration is greater than zero. The LRL is the concentration at which the false negative error rate is minimized to be no more than 1 percent of the reported results. The MRL uses a censor-limit based reporting level below which no data are reported and is set at a concentration greater than the detection limit of the analyte. The LRL generally is equal to twice the yearly determined LT-MDL, which is a detection level derived by determining the standard deviation of a minimum of $24 \mathrm{MDL}$ spike-sample measurements over an extended time. These reporting levels may be described as preliminary (IRL) for a developmental method if the levels have been based on a small number of analytical results. These levels also may vary from sample to sample for the same constituent and the same method, if matrix effects or other factors arise that interfere with the analysis. Concentrations measured between the LT-MDL and the LRL may be described as estimated values and are considered a "qualitatively detected analyte" (Childress and others, 1999, p. 7). For most of the constituents in this report, reported concentrations generally are greater than the LT-MDLs, LRLs, or MRLs, but some are given as less than the LT-MDL or LRL, and some are estimated.

As a matter of convention, concentrations of stable isotopes are reported as relative isotopic ratios (Toran, 1982). Busenberg and others (2000) described stable isotope data in more detail.

\section{Inorganic Chemistry Data}

Water samples collected in July 2013 from USGS 140 and in September 2013 from USGS 141 were sent to the NWQL to be analyzed for dissolved concentrations of (1) cations of calcium, magnesium, potassium, silica, and sodium; (2) anions of bromide, chloride, fluoride, and sulfate; and (3) trace elements of aluminum, antimony, arsenic, barium, beryllium, boron, cadmium, chromium, cobalt, copper, iron, lead, lithium, manganese, mercury, molybdenum, nickel, selenium, silver, strontium, thallium, tungsten, uranium, vanadium, and zinc. Additionally, samples were collected and sent to the NWQL to be analyzed for dissolved concentrations of ammonia as nitrogen $(\mathrm{N})$, nitrite as $\mathrm{N}$, nitrate plus nitrite as $\mathrm{N}$, and orthophosphate as phosphorus (P) (table 5).

A comparison of the data for the samples collected from wells USGS 140 and USGS 141 indicates very similar chemistry of the aquifer water at both wells (table 5). The water chemistry of both wells also is similar to that of well USGS 136 (Twining and others, 2012), which was drilled upgradient from wells USGS 140 and 141 (fig. 2). For example, concentrations of nitrate plus nitrite were 1.13, 1.09, and $1.07 \mathrm{mg} / \mathrm{L}$, respectively, for wells USGS 136, 140, and 141. Calcium concentrations were $50,55.9$, and $54.0 \mathrm{mg} / \mathrm{L}$, magnesium concentrations were $17.4,17.9$, and $17.1 \mathrm{mg} / \mathrm{L}$, sodium concentrations were $11,12.6$, and $11.4 \mathrm{mg} / \mathrm{L}$, and chloride concentrations were $12.9,12.6$, and $12.1 \mathrm{mg} / \mathrm{L}$ for wells USGS 136, 140, and 141, respectively. Background concentrations of dissolved chromium in the ESRP aquifer generally are about 2-3 $\mu \mathrm{g} / \mathrm{L}$ (Orr and others, 1991; Knobel and others, 1992), so concentrations of 18 and $15.9 \mu \mathrm{g} / \mathrm{L}$ in wells USGS 140 and USGS 141, respectively (table 5), probably can be attributed to wastewater disposal at the ATR Complex. Sulfate concentrations of 41.0 and $38.6 \mathrm{mg} / \mathrm{L}$ (table 5) were about $15-20 \mathrm{mg} / \mathrm{L}$ higher than background concentrations around the ATR Complex (20-25 mg/L; Robertson and others, 1974, fig. 27). Concentrations of chloride, sodium, and nitrate plus nitrite as $\mathrm{N}$ in both wells (table 5) were near background levels for the aquifer near the ATR Complex.

\section{Organic Chemistry Data}

Water samples collected in July 2013 from well USGS 140 and in September 2013 from well USGS 141 were analyzed at the NWQL for volatile organic compounds (VOCs). All concentrations of VOCs were below the LRL except toluene, which was detected in the samples collected at wells USGS 140 and USGS 141 at concentrations of $0.2 \mu \mathrm{g} / \mathrm{L}$ and $1.0 \mu \mathrm{g} / \mathrm{L}$, respectively (table 5). Toluene is a grease component used on pipe threads and is a product in fuels, so the small concentrations may have been a remnant of drilling activities. 


\section{Stable Isotope Data}

Water samples collected in July 2013 from well USGS 140 and in September 2013 from well USGS 141 were analyzed for relative concentrations of stable isotopes of hydrogen $(\mathrm{H})$, oxygen $(\mathrm{O})$, and carbon $(\mathrm{C})$. Because the absolute measurement of isotopic ratios is analytically difficult, relative isotopic ratios were measured instead (Toran, 1982). For example, ${ }^{18} \mathrm{O} /{ }^{16} \mathrm{O}$ of a sample is compared with ${ }^{18} \mathrm{O} /{ }^{16} \mathrm{O}$ of a standard:

$$
\text { Delta }{ }^{18} \mathrm{O}=\left(R_{\text {sample }} / R_{\text {standard }}\right)-1 \times 1,000
$$

where

$$
\begin{gathered}
R_{\text {sample }} \text { is the }{ }^{18} \mathrm{O} /{ }^{16} \mathrm{O} \text { ratio in the sample, } \\
R_{\text {standard }} \text { is the }{ }^{18} \mathrm{O} /{ }^{16} \mathrm{O} \text { ratio in the standard, and } \\
\text { Delta }{ }^{18} \mathrm{O} \text { is the relative concentration, in units of } \\
\text { parts per thousand. }
\end{gathered}
$$

Delta ${ }^{18} \mathrm{O}$ is referred to as delta notation; it is the value reported by isotopic laboratories for stable isotope analysis. ${ }^{2} \mathrm{H} /{ }^{1} \mathrm{H}$ and ${ }^{13} \mathrm{C} /{ }^{12} \mathrm{C}$ are defined in a similar manner with the respective ratios replacing ${ }^{18} \mathrm{O} /{ }^{16} \mathrm{O}$ in $R_{\text {sample }}$ and $R_{\text {standard. }}$. The standard used for determining Delta ${ }^{18} \mathrm{O}$ and Delta ${ }^{2} \mathrm{H}$ in water is standard mean ocean water as defined by Craig (1961). The PeeDee Belemnite reference standard was used to determine Delta ${ }^{13} \mathrm{C}$ in water (Timme, 1995, p. 71).

Stable isotope concentration data for deuterium, oxygen-18, and carbon-13 samples collected from USGS 140 and 141 were similar to concentrations of those constituents in USGS 136 sampled upgradient (Twining and others, 2012). For example, concentrations in USGS 140 (table 5) were $-8.38,-137.4$ and -17.85 per mil for carbon-13, deuterium, and oxygen-18, respectively. Concentrations for USGS 141 were not analyzed (carbon-13), -137.0 per mil (deuterium), and -17.85 per mil (oxygen-18). For USGS 136, the respective concentrations of carbon-13, deuterium, and oxygen-18 were $-8.33,-136.9$, and -17.9 .

\section{Radiochemical Data}

Water samples were collected in July 2013 from well USGS 140 and in September 2013 from well USGS 141, and were analyzed at the RESL for tritium; strontium-90; gross alpha, beta, and gamma radioactivity; iodine-129, technetium-99, plutonium-238, and plutonium-239, -240 (undivided); and americium-241. Additionally, samples were collected for uranium isotopes and analyzed by a USGS NWQL contract laboratory (table 5). Concentrations of all the radionuclides analyzed were less than the reporting level, except for tritium, carbon-14, uranium-234, and uranium-238 (table 5). Uranium isotope concentrations in samples collected from wells USGS 140 and 141 were similar to each other and to concentrations found in a sample from well USGS 136 (Twining and others, 2012). The elevated tritium concentrations indicate some influence from past wastewater disposal at the ATR Complex and were similar to concentrations in well USGS 136 (Twining and others, 2012).

Additionally, carbon-14 samples collected by the USGS for BEA and analyzed by GEL Laboratories, LLC (table 5), had concentrations greater than the reporting level in both well USGS $140(5.71 \pm 1.47 \mathrm{pCi} / \mathrm{L})$ and well USGS 141 $(8.04 \pm 1.74 \mathrm{pCi} / \mathrm{L})$. Carbon-14 has been detected in other wells within the ATR Complex contamination plume area (David Fredrick, Battelle Energy Alliance, written commun., 2013) and likely is the result of past wastewater disposal at the ATR Complex warm waste ponds.

\section{Summary}

In 2013, the U.S. Geological Survey, in cooperation with the U.S. Department of Energy, drilled and constructed boreholes USGS 140 and USGS 141 for stratigraphic framework analyses and long-term groundwater monitoring of the eastern Snake River Plain aquifer at the Idaho National Laboratory. Borehole USGS 140 initially was cored to collect continuous geologic data and then re-drilled to complete construction as a monitoring well. Borehole USGS 141 was drilled and constructed as a monitoring well. Boreholes USGS 140 and USGS 141 are separated by about 375 feet (ft) and have similar stratigraphic layers and hydrologic characteristics, determined from geophysical and aquifer test data collected. The final construction for boreholes USGS 140 and USGS 141 required 6-inch (in.) diameter carbon-steel well casing and 5-in. diameter stainless-steel well screen; the screened monitoring interval was completed about $50 \mathrm{ft}$ into the eastern Snake River Plain aquifer, between 496 and $546 \mathrm{ft}$ below land surface at both locations. Following construction and data collection, dedicated pumps and water-level access lines were placed to allow for aquifer testing, for collecting periodic water samples, and for measuring water levels.

Geophysical and borehole video logs were collected at various times during the drilling and construction process at boreholes USGS 140 and USGS 141. Geophysical logs were examined in conjunction with the core material for borehole USGS 140; additionally, geophysical data were examined from borehole USGS 141 (where core was not collected) to confirm geologic and hydrologic similarities between boreholes USGS 141 and USGS 140. Geophysical data suggest the occurrence of fractured and (or) vesiculated basalt, dense basalt, and sediment layering in both the saturated and unsaturated zones. Omni-directional density measurements were used to assess the completeness of grout annular seal behind 6-in. diameter well casing. Gyroscopic deviation measurements were used to measure horizontal and vertical deviation in boreholes USGS 140 and USGS 141. 
Single-well aquifer tests were performed following construction at wells USGS 140 and USGS 141 and data were used to provide estimates of specific-capacity, transmissivity, and hydraulic conductivity. The specific capacity, transmissivity, and hydraulic conductivity for well USGS 140 were estimated at 2,370 gallons per minute per foot $[(\mathrm{gal} / \mathrm{min}) / \mathrm{ft})], 4.06 \times 10^{5}$ feet squared per day $\left(\mathrm{ft}^{2} / \mathrm{d}\right)$, and 740 feet per day (ft/d), respectively. The specific capacity, transmissivity, and hydraulic conductivity for USGS 141 were estimated at $470(\mathrm{gal} / \mathrm{min}) / \mathrm{ft}, 5.95 \times 10^{4} \mathrm{ft}^{2} / \mathrm{d}$, and $110 \mathrm{ft} / \mathrm{d}$, respectively. Measured flow rates remained relatively constant in well USGS 140 with averages of 23.9 and $23.7 \mathrm{gal} / \mathrm{min}$ during the first and second aquifer tests, respectively, and in well USGS 141 with an average of $23.4 \mathrm{gal} / \mathrm{min}$.

Water samples were analyzed for cations, anions, metals, nutrients, total organic carbon, volatile organic compounds, stable isotopes, and radionuclides. Water samples from both wells indicated that concentrations of tritium, sulfate, and chromium were affected by wastewater disposal practices at the Advanced Test Reactor Complex. The volatile organic compound toluene was detected at small concentrations from both wells and may indicate some minor contamination from the drilling activities; however, no other organic compounds were detected. Most constituents in water from wells USGS 140 and USGS 141 had concentrations similar to concentrations in well USGS 136, which is upgradient from wells USGS 140 and USGS 141.

\section{References Cited}

Ackerman, D.J., 1991, Transmissivity of the Snake River Plain aquifer at the Idaho National Engineering Laboratory, Idaho: U.S. Geological Survey Water-Resources Investigations Report 91-4058 (DOE/ID-22097), 35 p. [Also available at http://pubs.er.usgs.gov/publication/ wri914058.]

Ackerman, D.J., Rattray, G.W., Rousseau, J.P., Davis, L.C., and Orr, B.R., 2006, A conceptual model of ground-water flow in the eastern Snake River Plain aquifer at the Idaho National Laboratory and vicinity with implications for contaminant transport: U.S. Geological Survey Scientific Investigations Report 2006-5122, 62 p. [Also available at http://pubs.usgs.gov/sir/2006/5122/.]

Anderson, S.R., Kuntz, M.A., and Davis, L.C., 1999, Geologic controls of hydraulic conductivity in the Snake River Plain aquifer at and near the Idaho National Engineering and Environmental Laboratory, Idaho: U.S. Geological Survey Water-Resources Investigations Report 99-4033 (DOE/ ID-22155), 38 p. [Also available at http://pubs.er.usgs.gov/ publication/wri994033.]
Anderson, S.R., and Liszewski, M.J., 1997, Stratigraphy of the unsaturated zone and the Snake River Plain aquifer at and near the Idaho National Engineering Laboratory, Idaho: U.S. Geological Survey Water-Resources Investigations Report 97-4183 (DOE/ID-22142), 65 p. [Also available at http://pubs.er.usgs.gov/publication/wri974183.]

Bartholomay, R.C., Tucker, B.J., Ackerman, D.J., and Liszewski, M.J., 1997, Hydrologic conditions and distribution of selected radiochemical and chemical constituents in water, Snake River Plain aquifer, Idaho National Engineering Laboratory, Idaho, 1992 through 1995: U.S. Geological Survey Water-Resources Investigations Report 97-4086 (DOE/ID-22137), 57 p. [Also available at http://pubs.er.usgs.gov/publication/ wri974086.]

Blackwell, D.D., Kelley, S., and Steele, J.L., 1992, Heat flow modeling of the Snake River Plain, Idaho: Idaho National Engineering Laboratory, Department of Energy contractor report no. EGG-NPR-10790, 109 p.

Bodnar, L.Z., and Percival, D.R., eds., 1982, RESL Analytical Chemistry Branch procedures manual: U.S. Department of Energy Report IDO-12096, 364 p.

Busenberg, Eurybiades, Plummer, L.N., and Bartholomay, R.C., 2001, Estimated age and source of the young fraction of ground water at the Idaho National Engineering and Environmental Laboratory: U.S. Geological Survey Water-Resources Investigations Report 2001-4265 (DOE/ ID-22177), $144 \mathrm{p}$.

Busenberg, Eurybiades, Plummer, L.N., Doughten, M.W., Widman, P.K., and Bartholomay, R.C., 2000, Chemical and isotopic composition and gas concentrations of ground water and surface water from selected sites at and near the Idaho National Engineering and Environmental Laboratory, Idaho, 1994-97: U.S. Geological Survey Open-File Report 2000-81 (DOE/ ID-22164), 51 p. [Also available at http:// pubs.er.usgs.gov/publication/ofr0081.]

Cecil, L.D., Welhan, J.A., Green, J.R., Frape, S.K., and Sudicky, E.R., 2000, Use of chlorine-36 to determine regional-scale aquifer dispersivity, eastern Snake River Plain aquifer, Idaho/USA in Nuclear instruments and methods in physics research section B-Beam interactions with materials and atoms: International Conference on Accelerator Mass Spectrometry, 8th, Vienna, Austria, 1999, v. 172, p. 679-687.

Childress, C.J.O., Foreman, W.T., Conner, B.F., and Maloney, T.J., 1999, New reporting procedures based on long-term method detection levels and some considerations for interpretations of water-quality data provided by the U.S. Geological Survey National Water Quality Laboratory: U.S. Geological Survey Open-File Report 99-193, 19 p. [Also available at http://water.usgs.gov/owq/OFR_99-193/.] 
Christensen Products, 1997, C Wireline System: website, accessed May 2008, at http://christensenproducts.com.

Craig, Harmon, 1961, Isotopic variation in meteoric water: Science, v. 133, p. 1,702-1,703.

Currie, L.A., 1984, Lower limit of detection-Definition and elaboration of a proposed position for radiological effluent and environmental measurements: U.S. Nuclear Regulatory Commission NUREG/CR-4007, 139 p.

Davis, L.C., 2010, An update of hydrologic conditions and distribution of selected constituents in water, Snake River Plain aquifer and perched groundwater zones, Idaho National Laboratory, Idaho, emphasis 2006-08: U.S. Geological Survey Scientific Investigations Report 2010-5197 (DOE/ID-22212), 80 p. [Also available at http://pubs.er.usgs.gov/publication/sir20105197.]

Davis, L.C., Bartholomay, R.C., and Rattray, G.W., 2013, An update of hydrologic conditions and distribution of selected constituents in water, eastern Snake River Plain aquifer and perched groundwater zones, Idaho National Laboratory, Idaho, emphasis 2009-11: U.S. Geological Survey Scientific Investigations Report 2013-5214, (DOE/ ID-22226), 90 p. [Also available at http://pubs.er.usgs.gov/ publication/sir20135214.]

Davis, L.C., Hannula, S.R., and Bowers, Beverly, 1997, Procedures for use of, and drill cores and cuttings available for study at, the Lithologic Core Storage Library, Idaho National Engineering Laboratory, Idaho: U.S. Geological Survey Open-File Report 97-124 (DOE/ID-22135), 31 p. [Also available at http://pubs.er.usgs.gov/publication/ ofr97124.]

Duke, C.L., Roback, R.C., Reimus, P.W., Bowman, R.S., McLing, T.L., Baker, K. E., and Hull, L.C., 2007, Elucidation of flow and transport processes in a variably saturated system of interlayered sediment and fractured rock using tracer tests: Vadose Zone Journal, v. 6, no. 4, p. $855-867$.

Faires, L.M., 1993, Methods of analysis by the U.S. Geological Survey National Water Quality LaboratoryDetermination of metals in water by inductively coupled plasma-mass spectrometry: U.S. Geological Survey OpenFile Report 92-634, 28 p. [Also available at http://pubs. er.usgs.gov/publication/ofr92634.]

Fishman, M.J., ed., 1993, Methods of analysis by the U.S. Geological Survey National Water Quality LaboratoryDetermination of inorganic and organic constituents in water and fluvial sediments: U.S. Geological Survey OpenFile Report 93-125, 217 p. [Also available at http://pubs. er.usgs.gov/publication/ofr93125.]
Fishman, M.J., and Friedman, L.C., eds., 1989, Methods for determination of inorganic substances in water and sediments: U.S. Geological Survey Techniques of WaterResources Investigations, book 5, chap. A1, 545 p. [Also available at http://pubs.usgs.gov/twri/twri5-a1/.]

Freeze, R.A., and Cherry, J.A., 1979, Groundwater: Englewood Cliffs, N.J., Prentice Hall, Inc., 604 p.

Garabedian, S.P., 1986, Application of a parameter-estimation technique to modeling the regional aquifer underlying the eastern Snake River Plain, Idaho: U.S. Geological Survey Water-Supply Paper 2278, 60 p. [Also available at http:// pubs.er.usgs.gov/publication/wsp2278.]

Goerlitz, D.F., and Brown, Eugene, 1972, Methods for analysis of organic substances in water: U.S. Geological Survey Techniques of Water-Resources Investigations, book 5, chap. A3, 40 p.

Halford, K.J., Weight, W.D., and Schreiber, R.P., 2006, Interpretation of transmissivity estimates from single-well pumping aquifer tests: Ground Water, v. 44, no. 3, p. $467-471$.

Helm-Clark, Catherine, Ansley, Shannon, McLing, Travis, and Wood, Tom, 2005, Borehole and well Middle-1823 and its relationship to the stratigraphy of the south-central Idaho National Laboratory: Idaho Completion Project, Idaho: ICP/ EXT-05-00790, Rev. 0 [variously paged].

Keys, W.S., 1990, Borehole geophysics applied to groundwater investigations: U.S. Geological Survey Techniques of Water-Resources Investigations, book 2, chap. E2, 150 p.

Knobel, L.L., Orr, B.R., and Cecil, L.D., 1992, Summary of background concentrations of selected radiochemical and chemical constituents in groundwater from the Snake River Plain aquifer, Idaho: estimated from an analysis of previously published data: Journal of the Idaho Academy of Science, v. 28, no. 1, p. 48-61.

Knobel, L.L., Tucker, B.J., and Rousseau, J.P., 2008, Field methods and quality-assurance plan for quality-ofwater activities, U.S. Geological Survey, Idaho National Laboratory, Idaho: U.S. Geological Survey Open-File Report 2008-1165 (DOE/ID-22206), 36 p. [Also available at http://pubs.usgs.gov/of/2008/1165/.]

Lane, J.W., Jr., Williams, J.H., Johnson, C.D., Savino, D.M., Sr., and Haeni, F.P., 2002, An integrated geophysical and hydraulic investigation to characterize a fractured-rock aquifer, Norwalk, Connecticut: U.S. Geological Survey Water-Resources Investigations Report 2001-4133, 97 p. 
Mann, L.J., 1986, Hydraulic properties of rock units and chemical quality of water for INEL-1-A 10,365-foot deep test hole drilled at the Idaho National Engineering Laboratory, Idaho: U.S. Geological Survey Water-Resources Investigations Report 86-4020 (IDO-22070), 23 p. [Also available at http://pubs.er.usgs.gov/usgspubs/wri/ wri864020.]

Mann, L.J., and Beasley, T.M., 1994, Iodine-129 in the Snake River Plain aquifer at and near the Idaho National Engineering Laboratory, Idaho, 1990-91: U.S. Geological Survey Water-Resources Investigations Report 94-4053 (DOE/ID-22115), 27 p. [Also available at http://pubs. er.usgs.gov/usgspubs/wri/wri944053.]

McCurdy, D.E., Garbarino, J.R., and Mullin, A.H., 2008, Interpreting and reporting radiological water-quality data: U.S. Geological Survey Techniques and Methods, book 5, chap. B6, 33 p. [Also available at http://pubs.usgs.gov/ $\mathrm{tm} / 05 \mathrm{~b} 06 /$.

Nimmo, J.R., Perkins, K.S., Rose, P.E., Rousseau, J.P., Orr, B.R., Twining, B.V., and Anderson, S.R., 2002, Kilometerscale rapid transport of naphthalene sulfonate tracer in the unsaturated zone at the Idaho National Engineering and Environmental Laboratory: Vadose Zone Journal, v. 1, no. 1, p. 89-101.

Orr, B.R., Cecil, L.D., and Knobel, L.L., 1991, Background concentrations of selected radionuclides, organic compounds, and chemical constituents in ground water in the vicinity of the Idaho National Engineering Laboratory: U.S. Geological Survey Water-Resources Investigations Report 91-4015 (DOE/ID-22094), 52 p. [Also available at http://pubs.er.usgs.gov/publication/wri914015.]

Pierce, K.L., and Morgan, L.A., 1992, The track of the Yellowstone hot spot, in Link, P.K., Kuntz, M.A., and Platt, L.B., eds., Regional geology of eastern Idaho and western Wyoming: Geological Society of America Memoir 179, p. $1-53$.

Pritt, J.W., 1989, Quality assurance of sample containers and preservatives at the U.S. Geological Survey National Water Quality Laboratory, in Pederson, G.L., and Smith, M.M., comps., U.S. Geological Survey second national symposium on water quality - Abstracts of the technical sessions: U.S. Geological Survey Open-File Report 89-409, 111 p. [Also available at http://pubs.er.usgs.gov/publication/ofr89409.]

Robertson, J.B., Schoen, Robert, and Barraclough, J.T., 1974, The influence of liquid waste disposal on the geochemistry of water at the National Reactor Testing Station, Idaho, 1952-1970: U.S. Geological Survey Open-File Report 73-238 (IDO-22053), $231 \mathrm{p}$.
Rose, D.L., and Schroeder, M.P., 1995, Methods of analysis by the U.S. Geological Survey National Water Quality Laboratory-Determination of volatile organic compounds in water by purge and trap capillary gas chromatography/ mass spectrometry: U.S. Geological Survey Open-File Report 94-708-W, 26 p. [Also available at http://pubs. er.usgs.gov/publication/ofr94708W.]

Self, S., Keszthelyi, L., and Thordarson, T., 1998, The importance of pahoehoe: Annual Review of Earth and Planetary Sciences, v. 26, p. 81-110.

Shervais, J.W., Vetter, S.K., and Hanan, B.B., 2006, Layered mafic sill complex beneath the eastern Snake River PlainEvidence from cyclic geochemical variations in basalt: Geology, v. 34, no. 5, p. 365-368.

Sill, D.S., and Sill, C.W., 1994, Simultaneous determination of the actinides in small environmental samples: Radioactivity and Radiochemistry, v. 5, no. 2, p. 8-19.

Thatcher, L.L., Janzer, V.J., and Edwards, K.W., 1977, Methods for determination of radioactive substances in water and sediments: U.S. Geological Survey Techniques of Water-Resources Investigations, book 5, chap. A5, 95 p. [Also available at http://pubs.usgs.gov/twri/twri5a5/.]

Theis, C.V., Brown, R.H., and Meyer, R.R., 1963, Estimating the transmissibility of aquifers from the specific capacity of wells, in Bentall, Ray, Methods of determining permeability, transmissibility and drawdown: U.S. Geological Survey Water-Supply Paper 1536-I, p. 331-341. [Also available at http://pubs.er.usgs.gov/publication/wsp15361.]

Timme, P.J., 1995, National Water Quality Laboratory, 1995 services catalog: U.S. Geological Survey Open-File Report 95-352, 120 p. [Also available at http://pubs.er.usgs. gov/publication/ofr95352.]

Toran, Laura, 1982, Isotopes in ground-water investigations: Ground Water, v. 20, no. 6, p. 740-745.

Twining, B.V., Bartholomay, R.C., and Hodges, M.K.V., 2012, Completion summary for borehole USGS 136 near the Advanced Test Reactors Facility, Idaho National Laboratory, Idaho: U.S. Geological Survey Scientific Investigations Report 2012-5230 (DOE/ID-22220), 32 p., plus appendixes. [Also available at http://pubs.er.usgs.gov/ publication/sir20125230.]

U.S. Department of Energy, 1995, Radiochemistry manual, rev. 10: Idaho Falls, Idaho, U.S. Department of Energy, Radiological and Environmental Sciences Laboratory [variously paged]. 
U.S. Department of Energy, 2003, Idaho National Engineering and Environmental Laboratory groundwater monitoring plan update: DOE/ID-11034, rev. 1, August 2003, [variously paged].

U.S. Geological Survey, 1985, National Water summary 1984-Hydrologic events, selected water-quality trends, and ground-water resources: U.S. Geological Survey WaterSupply Paper 2275, 467 p. [Also available at http://pubs. er.usgs.gov/publication/wsp2275.]

U.S. Geological Survey, 2010, Changes to the reporting convention and to data qualification approaches for selected analyte results reported by the National Water Quality Laboratory (NWQL): Office of Water Quality Technical Memorandum 2010.07, accessed June 9, 2011, at http:// water.usgs.gov/admin $/ \mathrm{memo} / \mathrm{QW} / \mathrm{qw} 10.07 . \mathrm{html}$.

U.S. Geological Survey, variously dated, National field manual for the collection of water-quality data: U.S. Geological Survey Techniques of Water-Resources Investigations, book 9, chaps. A1-A9, [Also available at http://water.usgs. gov/owq/FieldManual/.]
Wentworth, C.K., 1922, A scale of grade and class terms for clastic sediments: Journal of Geology, v. 30, p. 377-392.

Wershaw, R.L., Fishman, M.J., Grabbe, R.R., and Lowe, L.E., eds., 1987, Methods for the determination of organic substances in water and fluvial sediments: U.S. Geological Survey Techniques of Water-Resources Investigations, book 5, chap. A3, 80 p. [Also available at http://pubs. er.usgs.gov/publication/twri05A3.]

Whitehead, R.L., 1992, Geohydrologic framework of the Snake River Plain regional aquifer system, Idaho and eastern Oregon: U. S. Geological Survey Professional Paper 1408-B, 32 p. [Also available at http://pubs.er.usgs. gov/publication/pp1408B.]

Yearsley, Elliot N., Crowder, R.E., and Irons, L.A., 1991, Monitoring well completion evaluation with borehole geophysical density logging, in Ground Water Monitoring Review, v. XI, no. 2, 9 p. 



\section{Appendixes}

Appendixes A-C are available for download as a PDF at http://pubs.usgs.gov/sir/2014/5098.

\section{Appendix A. Material Safety Data Sheets for Drilling Mud}

Appendix B. Core Log for USGS 140

Appendix C. Aquifer Test Measurements During Testing at Wells USGS 140 and USGS 141 

Publishing support provided by the U.S. Geological Survey Publishing Network, Tacoma Publishing Service Center

For more information concerning the research in this report, contact the Director, Idaho Water Science Center

U.S. Geological Survey

230 Collins Road

Boise, Idaho 83702

http://id.water.usgs.gov 
동

㤩

들

궁

훌

둥

옹

$\leqslant$ 